This is the final peer-reviewed accepted manuscript of

Ricchi, Alessandro; Quartau, Rui; Ramalho, Ricardo S.; Romagnoli, Claudia; Casalbore, Daniele; Ventura da Cruz, João; Fradique, Catarina; Vinhas, André: Marine terrace development on reefless volcanic islands: New insights from high-resolution marine geophysical data offshore Santa Maria Island (Azores Archipelago). MARINE GEOLOGY, 406. 0025-3227

DOI: 10.1016/j.margeo.2018.09.002

The final published version is available online at:

http://dx.doi.org/10.1016/i.margeo.2018.09.002

Rights / License:

The terms and conditions for the reuse of this version of the manuscript are specified in the publishing policy. For all terms of use and more information see the publisher's website.

This item was downloaded from IRIS Università di Bologna (https://cris.unibo.it/)

When citing, please refer to the published version. 


\title{
Marine terrace development on reefless volcanic islands: New insights from high-resolution marine geophysical data offshore Santa Maria Island (Azores Archipelago)
}

\author{
Alessandro Ricchi ${ }^{\mathrm{a}, *}$, Rui Quartau ${ }^{\mathrm{b}, \mathrm{c}}$, Ricardo S. Ramalho ${ }^{\mathrm{c}, \mathrm{d}, \mathrm{e}}$, Claudia Romagnoli ${ }^{\mathrm{a}}$, \\ Daniele Casalbore ${ }^{\mathrm{f}, \mathrm{g}}$, João Ventura da Cruz ${ }^{\mathrm{b}}$, Catarina Fradique ${ }^{\mathrm{b}}$, André Vinhas ${ }^{\mathrm{b}}$ \\ a University of Bologna, Dip. Scienze Biologiche, Geologiche e Ambientali, Bologna, Italy \\ ${ }^{\mathrm{b}}$ Instituto Hidrográfico, Divisão de Geologia Marinha, Lisboa, Portugal \\ ${ }^{\mathrm{c}}$ Instituto Dom Luiz, Faculdade de Ciências, Universidade de Lisboa, Lisboa, Portugal \\ ${ }^{\mathrm{d}}$ School of Earth Sciences, University of Bristol, Bristol, UK \\ e Lamont-Doherty Earth Observatory at Columbia University, Palisades, NY, USA \\ ${ }^{\mathrm{f}}$ Sapienza Università di Roma, Dipartimento Scienze della Terra, Roma, Italy \\ ${ }^{\mathrm{g}}$ Istituto di Geologia Ambientale e Geoingegneria, Consiglio Nazionale delle Ricerche, Area della Ricerca, Roma, Italy
}

Editor: E. Anthony

Keywords:

Insular shelf

Marine terraces

Uplift trend

Reefless volcanic islands

Multibeam bathymetry

\begin{abstract}
Submerged marine terraces are relict coastal erosional landforms now underwater due to rising sea level and/or land subsidence. Using as case study the shelf around Santa Maria Island (North Atlantic Ocean), we intend to advance our knowledge on the formation and preservation of these features on reefless volcanic islands. Santa Maria is an ideal place to study their combined generation, since it displays a sequence of subaerial and submerged marine terraces (the latter not studied before), distributed between $7 / 230 \mathrm{~m}$ in elevation, and 40/

$140 \mathrm{~m}$ in depth, respectively. Based on some geological constraints, we investigated a possible correlation between the formation of the different terraces with known sea-level changes. Our results suggest that the spatial distribution of marine terraces at Santa Maria depends on the complex interplay between glacio-eustatic sealevel fluctuations, the island's vertical motion trends, the morphology of the shelf, and the intensity of marine erosion. Subaerial terraces probably developed from $\sim 3.5 \mathrm{Ma}$ to $\sim 1 \mathrm{Ma}$ following a fortuitous conjugation of optimal exposure to energetic waves and a suitable arrangement/lithology of the stratigraphic units promoting easier erosion. Their preservation was likely promoted by the uplift trend the island experienced in the last 3.5 Ma, which was rapid enough to prevent their destruction by subsequent highstands. The submerged terraces, presumably all younger than $\sim 1 \mathrm{Ma}$, were largely influenced by shelf gradient, leading to more developed and preserved terraces in wider and low-gradient sectors. Displacement by active faults also conditioned the formation and further development of both subaerial and submerged terraces, with tectonic activity documented for the $0.693 \mathrm{Ma}-2.7$ Ma period.
\end{abstract}

\section{Introduction}

Relative sea level changes have left unambiguous morphologies in the geological record, as attested by the presence of coastal notches (e.g. Ferranti et al., 2006; Trenhaile, 2015), marine terraces (e.g. Zazo et al., 2002; Pedoja et al., 2014) and beach rocks (e.g. Mauz et al., 2015). In submarine settings the effects of glacio eustatic sea level changes can be witnessed by markers such as the shelf breaks on insular shelves (Quartau et al., 2014) or depositional features formed below storm wave base (e.g. submarine prograding wedges; Casalbore et al.,
2017 and references therein). Marine terraces are frequently referred to as excellent tracers of palaeo sea level (Pirazzoli et al., 1993) and they can be used to discern the vertical movements affecting the coastline (Campbell, 1986; Ferranti et al., 2006; Zazo et al., 2007). This approach has been successfully applied to study the history of uplifting volcanic islands (see Lucchi et al., 2007; Lucchi, 2009 and Ramalho et al., 2017) where vertical deformations usually operate at varied timescales (De Guidi and Monaco, 2009; Ramalho et al., 2013). Most studies so far do not integrate the offshore information (Quartau and Mitchell, 2013; Quartau et al., 2015a, 2015b), and when they did, mostly focused on

\footnotetext{
* Corresponding author.

E-mail address: alessandro.ricchi7@unibo.it (A. Ricchi).
} 
oceanic islands surrounded by coral reefs (Coulbourn et al., 1974; Blanchon and Jones, 1995; Faichney et al., 2010). To date, only few studies have looked closely at submerged terraces on reefless volcanic islands or at seamounts (Passaro et al., 2011; Schwartz et al., 2018) and consequently little is known about the factors that control the generation and timing of submerged terraces in these settings.

Santa Maria is the southeastern most and oldest island of the Azores Archipelago in the Atlantic Ocean, with a history of intermittent volcanism spanning between approximately 6 to 2.8 Ma (Sibrant et al., 2015; Ramalho et al., 2017). Its subaerial evolution is now well constrained (Serralheiro et al., 1987; Serralheiro, 2003; Ávila et al., 2008; Sibrant et al., 2015; Ramalho et al., 2017) and so is the history of vertical movements affecting the island edifice. Based on several volcanic, erosional, and sedimentary relative sea level markers found on shore, Ramalho et al. (2017) inferred that Santa Maria was subjected to over $200 \mathrm{~m}$ of subsidence from emergence at $6 \mathrm{Ma}$ until 3.5 Ma BP (at average $\sim 100 \mathrm{~m} / \mathrm{m}$.yr), after which the island experienced an uplift trend at a slower pace $(\sim 60 \mathrm{~m} / \mathrm{m}$.yr on average) until recent times. Additionally, Ramalho et al. (2017) reported a sequence of subaerial marine terraces at elevations ranging between $711 \mathrm{~m}$ and $210230 \mathrm{~m}$, formed during the post erosional stage of the island. In this paper, the analysis of newly acquired high resolution multibeam bathymetry and seismic profiles reveal a sequence of submerged marine terraces ex tending to the shelf edge. This makes Santa Maria an ideal case study to employ a combined onshore/offshore approach to investigate the generation of subaerial and submerged marine terraces and their likely timing of formation in relation to the island's vertical motion history. Based on one dated subaerial terrace and a dated passage zone between subaerial and submarine lava flows (which were used as "anchor" points), we also present a possible correlation between each subaerial and submerged terrace identified on the island and their respective possible time of formation, as extracted from published eustatic curves. The case study of Santa Maria therefore will improve our understanding of the controlling mechanisms of marine terrace formation and preservation at reefless volcanic islands, and more generally in other settings.

\section{Geological background}

The Azores Archipelago consists of a group of nine volcanic islands in the mid North Atlantic, located around the triple junction between the North American, Eurasian and Nubian lithospheric plates (Fig. 1). The Eastern (São Miguel and Santa Maria) and Central group of islands (Terceira, Graciosa, São Jorge, Pico, and Faial Islands) are located on a roughly triangular shaped area between the Terceira Rift (TR in Fig. 1) and the inactive East Azores Fracture Zone (EAFZ in Fig. 1) on the eastern side of the Mid Atlantic Ridge (MAR in Fig. 1; Lourenço et al., 1998; Gente et al., 2003; Miranda et al., 2018). This complex volcanotectonic structure is the result of a right transtensional shear zone that links the MAR with the Gloria Fault (GF) (Hipólito et al., 2013; Lourenço et al., 1998; Marques et al., 2013). Santa Maria Island is considered now outside the influence of such wide structure after a ridge jump, occurred at $\sim 4 \mathrm{Ma}$, from the incipient Princess Alice Rift (PAR in Fig. 1) to the present day Terceira Rift (Miranda et al., 2018).

Santa Maria was the first island in the Azores Archipelago to emerge above sea level, at approximately $6 \mathrm{Ma}$ (Ramalho et al., 2017). The present day edifice rises from the $-2500 \mathrm{~m}$ isobath to a summit at 587 $\mathrm{m}$ (Pico Alto, Fig. 2). The emergent stage of island building cor responds to the Cabrestantes and Porto Formations, which crop out on the western side of the island (age $\sim 6 \mathrm{Ma}$, Fig. 2a). Then, a subaerial shield volcano was formed about 5.8 5.3 Ma, which consolidated the island edifice (Anjos Volcanic Complex, Fig. 2a). During the following $\sim 1 \mathrm{Ma}$, volcanic activity waned, leading to a partial or complete dis mantling of the shield volcano and to marine deposition synchronous with occasional, low volume submarine volcanism (Touril Volcano sedimentary Complex, Fig. 2a). This stage is considered as mainly erosional and occurred alongside a significant subsidence trend, which further contributed to the planation and possibly complete submergence of the island edifice (Ramalho et al., 2017). At $4.1 \mathrm{Ma}$, however, renewed volcanic activity, which culminated in the creation of the Pico Alto Volcanic Complex (Fig. 2a), caused the edifice to reemerge, as attested by the vertical succession of submarine and subaerial volcanic products. At $\sim 3.5$ Ma subsidence reversed into uplift, as attested by the presence of raised submarine volcanic sequences and a succession of subaerial marine terraces on the western (windward) side (Ramalho et al., 2017), arranged in a typical staircase morphology. Conversely, the eastern (leeward) side is characterized by a rugged morphology, featuring high plunging cliffs (up to $250300 \mathrm{~m}$ in elevation) with occasional wave cut notches at varying elevations. A last stage of volcanism (3.2 2.8 Ma) created the Feteiras Formation (Fig. 2a), but this activity did not reverse the dominantly erosional trend the island has experienced in the last 3.5 Ma (Ramalho et al., 2017).

In terms of tectonics, Santa Maria is mainly dominated by NW SE, N S and NE SW trending extensional faults (Madeira et al., 2015), as attested by the existence of main morphological lineaments in the subaerial topography that displace some of the subaerial terraces (Fig. 2a; Madeira et al., 2015). Numerous dikes, contemporaneous with the two main shield building stages, striking $\mathrm{N} 045^{\circ}$ and $\mathrm{N} 150^{\circ}$ have also been reported (Zbyszewski and Ferreira, 1960; Serralheiro et al., 1987) (Fig. 2a).

In the Azores Archipelago the wave regime is dominated by waves impacting the coastline from the NW (29\%), W (24\%) and N (16\%), with average significant heights $\left(\mathrm{H}_{\mathrm{s}}\right)$ ranging between $2.5 \mathrm{~m}$ and $3 \mathrm{~m}$ (Quartau et al., 2012). Storminess in the Azores is high, and the archipelago is struck by severe storms, at least once every seven years (Andrade et al., 2008) that are able to produce maximum wave heights up to $20 \mathrm{~m}$ (Rusu and Guedes Soares, 2012). The Azores is subjected to semidiurnal regular tides and the annual mean tidal range in Santa Maria Island is about 1,44 m (Instituto Hidrográfico, 2000).

\section{Data and methods}

\subsection{Marine geophysical data acquisition}

High resolution multibeam bathymetric and seismic reflection data were collected around Santa Maria during the PLATMAR cruise between $-20 \mathrm{~m}$ and $-250 \mathrm{~m}$ onboard the R/V Arquipélago from 24th August to 15th September 2016. High resolution multibeam bathy metry was collected mostly parallel to the isobaths along overlapping track lines, relying on DGPS with OMNISTAR corrections for posi tioning and using a pole mounted Kongsberg EM2040C ${ }^{\mathrm{TM}}$ system (operating frequency range of $200400 \mathrm{kHz}$ and angular coverage of $130^{\circ}$ ). Sound velocity profiles (SVP, yellow dots, Fig. 3) were regularly collected during the survey. Data were processed using Caris Hips \& Sips 9.0 software to produce high resolution digital elevation models (DEMs) with variable cells size depending on the water depth ( $1 \mathrm{~m}$ for shallow water to $8 \mathrm{~m}$ at $\sim 250 \mathrm{~m}$ ).

A total of $2008 \mathrm{~km}$ of high resolution seismic profiles (Fig. 3) was also acquired between $-25 \mathrm{~m}$ and $-300 \mathrm{~m}$ using an Applied Acoustic Engineering AA 200 Boomer $^{\mathrm{TM}}$ plate and a receiver array consisted of a single channel streamer with 8 hydrophones. Most of the seismic profiles were acquired using 100/200 J of output energy, depending on the water depth. Seismic survey lines parallel to bathymetry have line spacing varying with depth (between 20 and $200 \mathrm{~m}$ ), whilst seismic lines perpendicular to the coastline were regularly spaced at $\sim 250 \mathrm{~m}$.

\subsection{Terrace mapping}

Multibeam bathymetry and seismic profiles were combined with an existing onshore topographical model (generated from a 1:5000 scale digital altimetric database) in a GIS environment, allowing for 


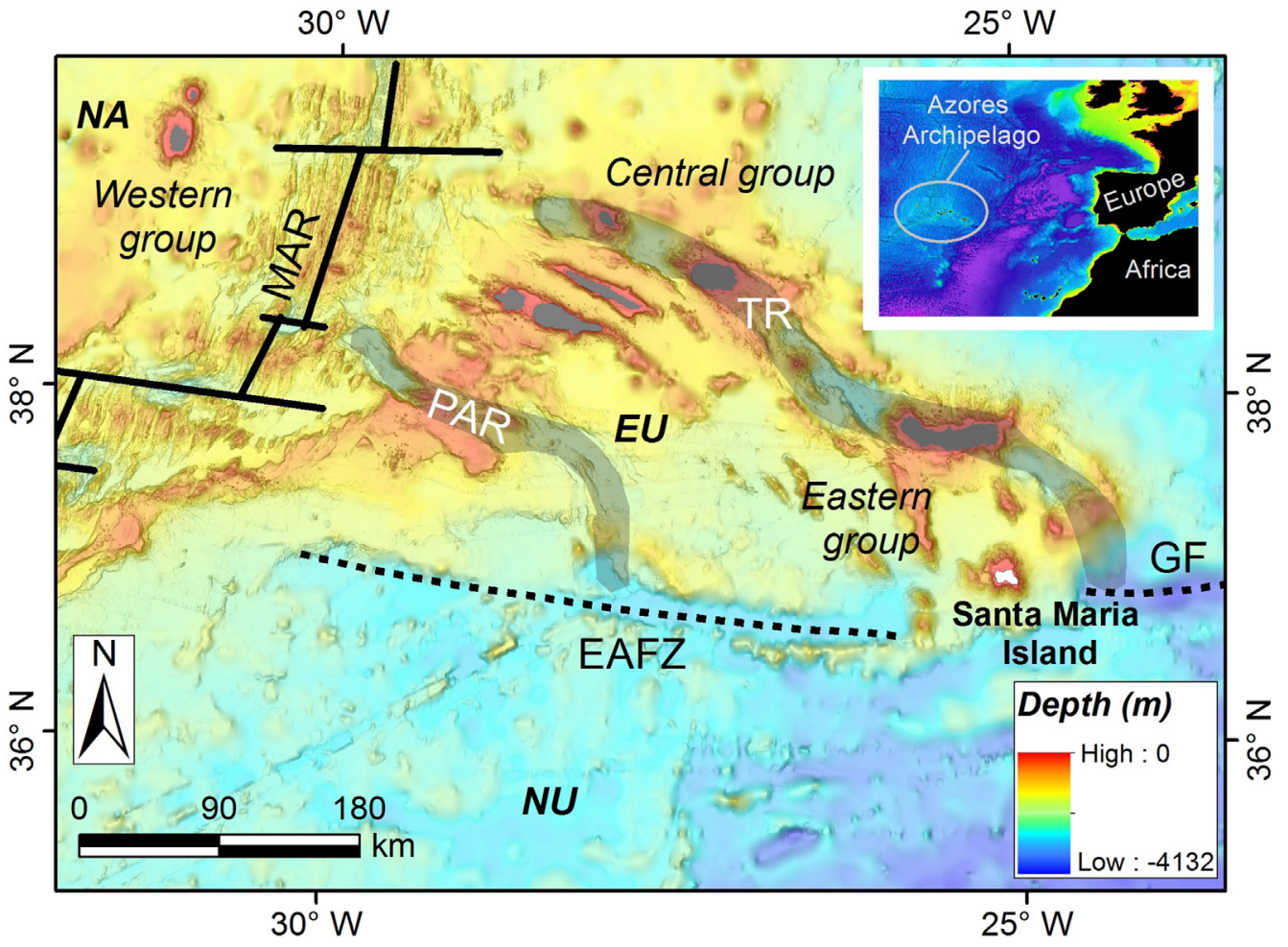

Fig. 1. Shaded relief map illustrating the geodynamic setting of the islands (western, central and eastern groups) in the Azores Archipelago (islands in grey, Santa Maria Island in white) and how they straddle the triple junction between the North American (NA), Eurasian (EU) and Nubian (NU) lithospheric plates. MAR: Mid-Atlantic Ridge; PAR: Princess Alice Rift; EAFZ: Eastern Azores Fracture Zone; TR: Terceira Rift; GF: Gloria Fault. The topright inset shows the geographical setting of the Azores Archipelago within the Northern Atlantic Ocean. Grey shading represents the deformation zone of Terceira rift and of the inactive Princess Alice Rift.

The bathymetry is derived from the EMODNET web portal (http://portal. emodnet-bathymetry.eu), tectonic structures adapted from Miranda et al. (2018). integrated onshore/offshore geomorphological analysis. Using this database, we mapped the erosive shelf edge and the submerged terraces on the shelf. Specifically, we mapped (where possible) the inner margin of each terrace (Fig. 4, also named "shoreline angle"), which provides an estimation of the shoreline position at the time it was formed, within an error of few meters (Firth et al., 1996; Trenhaile, 2002; Antonioli et al., 2003). Where the shelf and overlying terraces are covered by sediment, we used seismic profiles to measure their extension and edge depth. In such cases a sound velocity of $1800 \mathrm{~m} / \mathrm{s}$ was adopted for the time/ velocity conversion for sediments, which on the Azorean mid/outer shelves often correspond to sands (Quartau et al., 2012).

The mapped shelf was divided into four sectors (north, west, south, east), based on their orientation to the wave climate, their distinctive morphology and the distribution of submerged terraces (Figs. 5, 7 10; 3 and 8 on the Electronic supplementary material, hereafter ESM). To consider the island vertical movements, we always took into account the maximum values of the shelf edge depths for each sector, since later retrogressive erosion might have affected its depth, making it shallower in places. Mean values of the terrace width were calculated from bathymetric profiles plotted every $250 \mathrm{~m}$ perpendicular to the coastline and/or the shelf edge (Fig. 8ESM). The width of the subaerial terraces was also measured using topographic profiles (Fig. 8ESM and Table $3 \mathrm{ESM}$ ) to obtain average values, assuming that it corresponds to the distance from one palaeoshoreline to the one immediately above or below.

\subsection{Estimate of the age of subaerial and submerged marine terraces}

The uplift rates of Santa Maria were calculated using two dated subaerial markers, together with published sea level curves. Considering the time period under analysis (almost $4 \mathrm{Ma}$ ) we merged the Bintanja and van de Wal's (2008) curve, which has a very good resolution and covers $3 \mathrm{Ma}$, with a curve having a lower resolution (De Boer et al., 2010) for periods after 3 Ma (Fig. 6).

The subaerial marine terrace at $90 \mathrm{~m}$ above sea level (a.s.l.; dated at $2.15 \pm 0.03 \mathrm{Ma}$, Ramalho et al., 2017) and the maximum highstand between $2.12 \mathrm{Ma}$ and $2.18 \mathrm{Ma}(-0.47 \mathrm{~m}$ at $2.134 \mathrm{Ma}$ ) were used as reference markers to calculate the possible uplift rate, assuming that during that period this terrace was uplifted from $-0.47 \mathrm{~m}$ to $90 \mathrm{~m}$ a.s.l. Using this methodology, we obtained an average uplift rate of $42.4 \mathrm{~m} /$ m.yr $(0.042 \mathrm{~mm} / \mathrm{yr})$. The passage zone between subaerial and submarine lava flows of the effusive lava deltas of Monte Gordo (Fig. 2a) was chosen as another reference sea level marker to calculate an earlier uplift trend. This feature, that marks very accurately the position of sea level at the moment of the eruption (e.g. Cas and Wright, 1987; Porębski and Gradziński, 1990; Ramalho et al., 2010a, 2010b, 2010c; Ramalho, 2011; Meireles et al., 2013), is located at $190 \mathrm{~m}$ a.s.l. and its timing of formation is constrained by two ${ }^{40} \mathrm{Ar} /{ }^{39} \mathrm{Ar}$ analyses (SMA 18 and SMA 45 samples collected in the submarine lava flows below the passage zone) yielding ages of $3.63 \pm 0.09$ and $3.71 \pm 0.08 \mathrm{Ma}$ (see Ramalho et al., 2017). Although the formation of this lava delta did not occur, necessarily, during a highstand, the temporally nearest high stand provides a minimum value for the inferred vertical displacement experienced by this marker, which constitutes the highest datable sea level indicator in Santa Maria (Ramalho et al., 2017). The average age of the marker is $3.67 \mathrm{Ma}$, which falls between two highstands in our composite curve. Therefore, we used the nearest and highest highstand (dated as $3.704 \mathrm{Ma}$, at $6.4 \mathrm{~m}$ above present sea level) to calculate the average uplift rate, which is approximately $59 \mathrm{~m} / \mathrm{m} . y r(0.059 \mathrm{~mm} / \mathrm{yr})$. The result is an uplift rate that progressively slowed down with time, in agreement with the current elevation of the Marine Isotope Stage (MIS) 5e raised terrace $(711 \mathrm{~m}$ a.s.1.), which attests to a substantial vertical stability, or to very small uplift, on Santa Maria Island in the last $125 \mathrm{ka}$.

The composite sea level curve, based on the literature, has been modified according to the obtained uplift rates (Fig. 6), in order to infer the possible age of formation of the mapped marine terraces. Accord ingly, we tentatively matched all the stands (including highstands, stillstands and lowstands) and all the passing sea level cycles (rises and falls) with the current terrace elevation/depth (see Section 4.3). We assumed that subaerial and submerged marine terraces could be multigenerational, i.e. their geometry could result from the action of several stillstands, as well as sea level passages. We are, in fact, aware of the inherent errors of using one sea level curve in detriment of another 


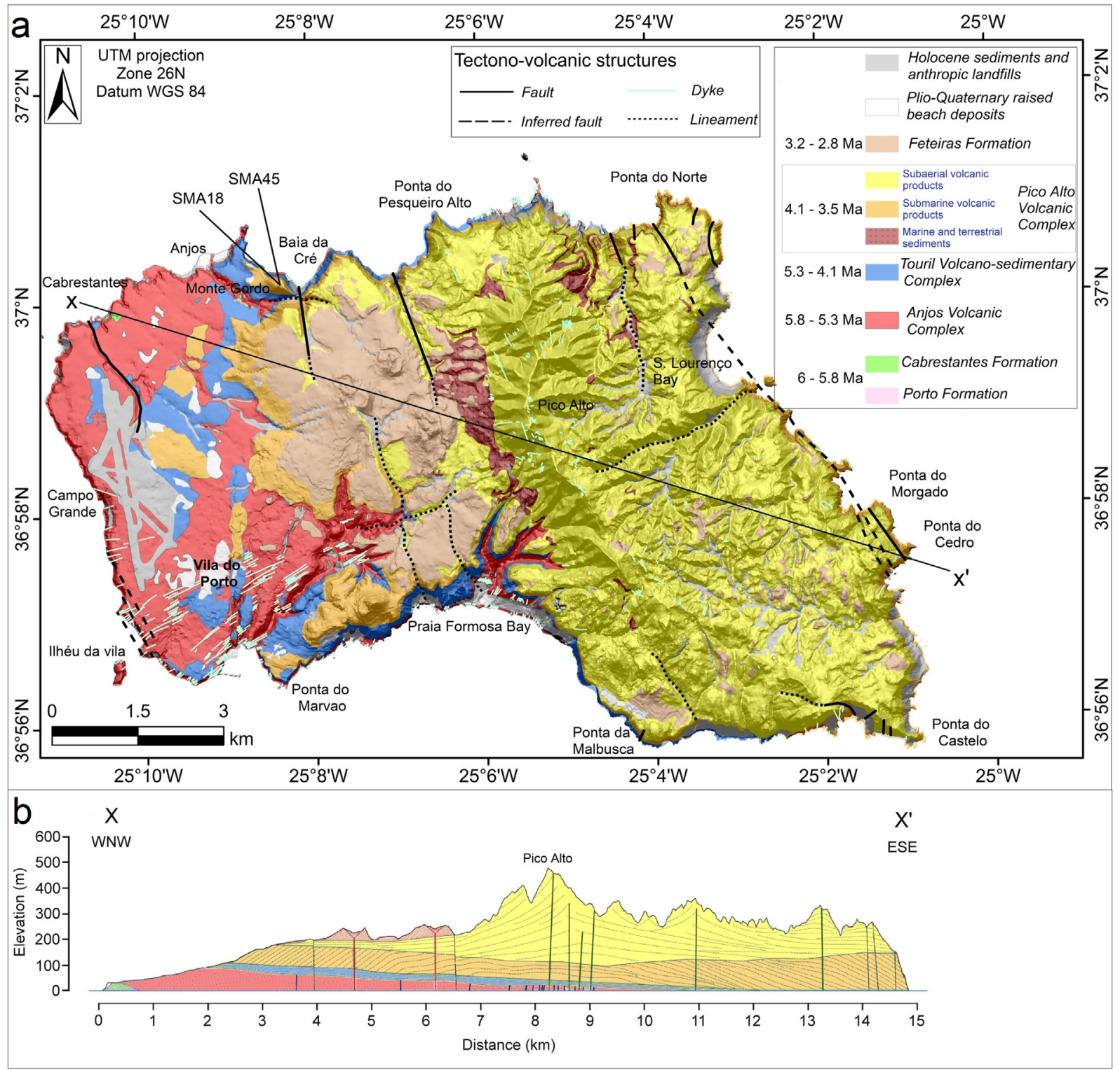

Fig. 2. (a) Geological map of Santa Maria Island, and (b) WNW-ESE oriented cross-section. Underlying digital elevation model (DEM) is generated from a $1 / 5000$ scale digital altimetric database from Secreteria Regional do Turismo e Trasportes of the Azores Government. Note that the Porto Fm and Lower Pico Alto volcanic complex are not visible on the map/section at this scale. SMA 18 and SMA 45: samples collected in the submarine lava flows below the passage zone of Monte Gordo (see the text for further details).

Modified after Ramalho et al. (2017).

(Caputo, 2007) and also that uplift rates have possibly changed through time in the period of our reconstruction (Ramalho et al., 2010b). Although a confident correlation between a particular terrace and a single sea level stand is impossible, the establishment of a probable time frame for its likely formation can be proposed. Moreover, we also took into account the time that waves eventually would take to carve the terraces at a specific depth, within a $\pm 5 \mathrm{~m}$ uncertainty (i.e., we con sidered also for the calculations the timing that sea was within $5 \mathrm{~m}$ above and below the level of the terrace) (see Table 1ESM).

\section{Results}

\subsection{The insular shelf around Santa Maria Island}

The northern sector of the shelf (Fig. 7) has a rough trapezoidal shape, being widest in front of Ilhéu das Lagoinhas $(\sim 8 \mathrm{~km})$ and narrower westwards $(\sim 4.5 \mathrm{~km})$. The northwestern most tip of the shelf is characterized by an oval shaped, $200 \mathrm{~m}$ high conical structure (Baixa doAmbrósio) that likely represents the remnants of an old pillow lava cone. Other concentric structures, probably corresponding to truncated cinder/scoria cones of the Cabrestantes and Porto Formations, and of the Anjos Volcanic Complex have been also identified, mostly on the easternmost portion from $-120 \mathrm{~m}$ to $-30 \mathrm{~m}$. The westernmost portion of the inner shelf is divided into three rocky blocks by sharp and linear escarpments ( 2 to $2.5 \mathrm{~km}$ long, Fig. 7) that are, apparently, the seaward expression of tectonic lineaments recognized on land (Aeroporto, Anjos and Baía da Cré faults in Figs. 2 and 7). The shelf edge depth is constantly below $-125 \mathrm{~m}$ with maximum depths of $\sim-170 \mathrm{~m}$ to NW off Baía do Mar da Barca (Fig. 7).

The western sector of the shelf is generally characterized by a rocky surface with almost no sediment cover. A WNW ESE lineament located offshore Campo Grande (possible fault, Fig. 8), separates the shelf into two parts characterized by different widths $(\sim 1 \mathrm{~km}$ to the north, $\sim 2 \mathrm{~km}$ to the south). In this sector the erosive shelf edge has been significantly 


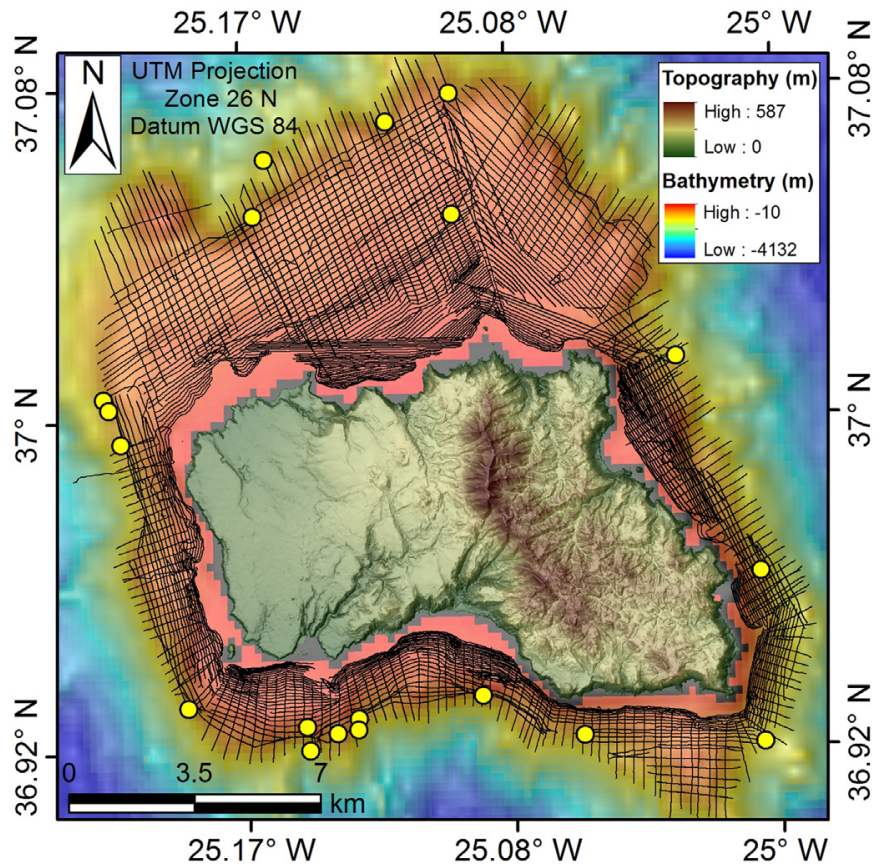

Fig. 3. Dataset used for this study, showing the seismic reflection profiles acquired during the PLATMAR cruise. The multibeam survey covered the area shown by the seismic grid. Yellow dots represent location of sound speed profiles collected during the multibeam survey. Bathymetry shown in this figure $(\sim 200$ $\mathrm{m}$ resolution) was derived from the EMODNET web portal (http:// portal.emodnet-bathymetry.eu); topography was constructed from a 1/5000 scale digital altimetric database. (For interpretation of the references to colour in this figure legend, the reader is referred to the web version of this article.)

affected by mass wasting; where preserved, its depth varies between $-100 /-110 \mathrm{~m}$ and $-135 /-145 \mathrm{~m}$ (Fig. 8).

The southern shelf sector has an irregular morphology, since more preserved and wider portions of the shelf alternate with narrower areas affected by gully heads (Fig. 9). Accordingly, the shelf width varies from $\sim 0.7 \mathrm{~km}$ to up to $\sim 2.5 \mathrm{~km}$ and the edge depth from $-80 /-90 \mathrm{~m}$ to a maximum value of $-142 \mathrm{~m}$ (Fig. 9). Sharp NNE SSW oriented lineaments cut the shelf, often defining rocky structural highs, which are bordered by more depressed areas covered by sediments (Fig. 9).

The eastern sector of the shelf is from $\sim 1$ to $\sim 2 \mathrm{~km}$ wide, with the erosive shelf edge located at a fairly constant depth, varying mostly between $-90 \mathrm{~m}$ and $-110 \mathrm{~m}$ (Fig. 10). Some portions of the outer shelf are affected by landslides which contributed to a decline in the shelf width and the depth of its edge. The morphology of the shelf is generally rough and thus associated with rocky outcrops alternating with patchy sedimentary cover, similar to the southern sector.

\subsection{Submerged marine terraces}

Five sets of marine terraces, with their inner margins located approximately at $-40 /-50 \mathrm{~m},-70 /-80 \mathrm{~m},-85 /-90 \mathrm{~m},-100 /$ $-110 \mathrm{~m}$ and $-120 /-140 \mathrm{~m}$ were identified on the shelf around Santa Maria (Figs. 7 to 14 and 1ESM to 7ESM).

\subsubsection{Terrace at $-40 /-50 \mathrm{~m}$}

This terrace is marked by an inner margin generally located between $-40 \mathrm{~m}$ and $-50 \mathrm{~m}$ (black line in Figs. 710,12 14, and 4ES $\mathrm{M}$ 7ESM), whilst the outer edge depth varies between $-50 \mathrm{~m}$ and $-60 \mathrm{~m}$. Overall, this terrace exhibits a patchy distribution on the northern sector and is narrow ( $\sim 400 \mathrm{~m}$, Fig. 7 and Table 2ESM) when compared to other terraces and to the shelf extent in the north. This terrace is $\sim 200 \mathrm{~m}$ wide along the western shelf sector (Table 3ESM) extending to $\sim 300 \mathrm{~m}$ and $\sim 400 \mathrm{~m}$, respectively, along the southern and the eastern shelf sectors; it is wider than the remaining terraces on the western, southern and eastern shelf sectors (Figs. 8, 10, 16 and Table 2ESM). The terrace is laterally discontinuous as it is interrupted by tectonic lineaments in the northern and western shelf sectors (respectively offshore Baía do Mar da Barca Baía da Cré and Campo Grande, Figs. 7 and 8) and is compartmentalized by rocky blocks in the southern and eastern sectors (Figs. 9 and 10).

\subsubsection{Terrace at $-70 /-80 \mathrm{~m}$}

The terrace with an inner edge located at $-70 /-80 \mathrm{~m}$ is evident in

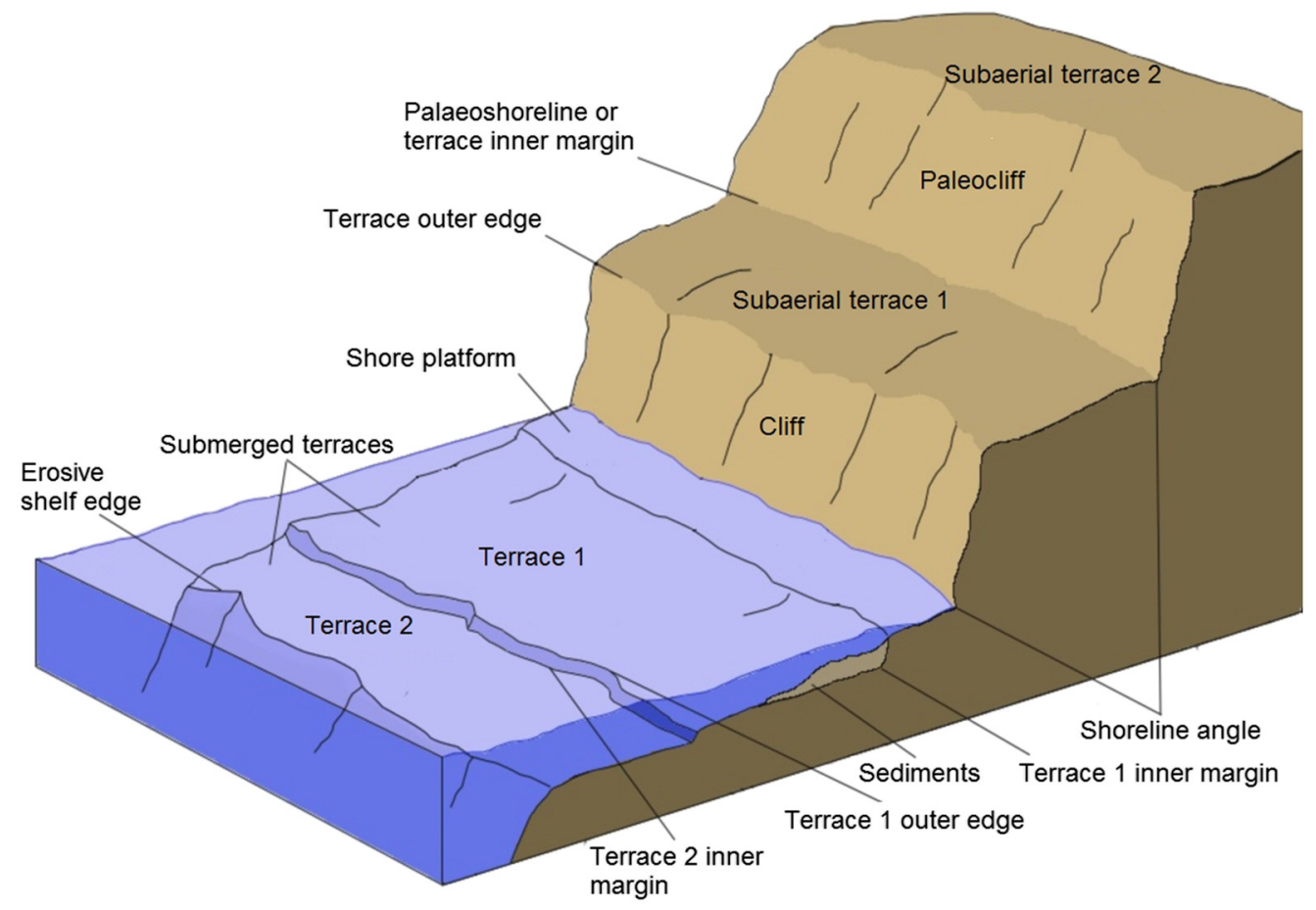

Fig. 4. Sketch showing the morphologic elements considered in this work. 


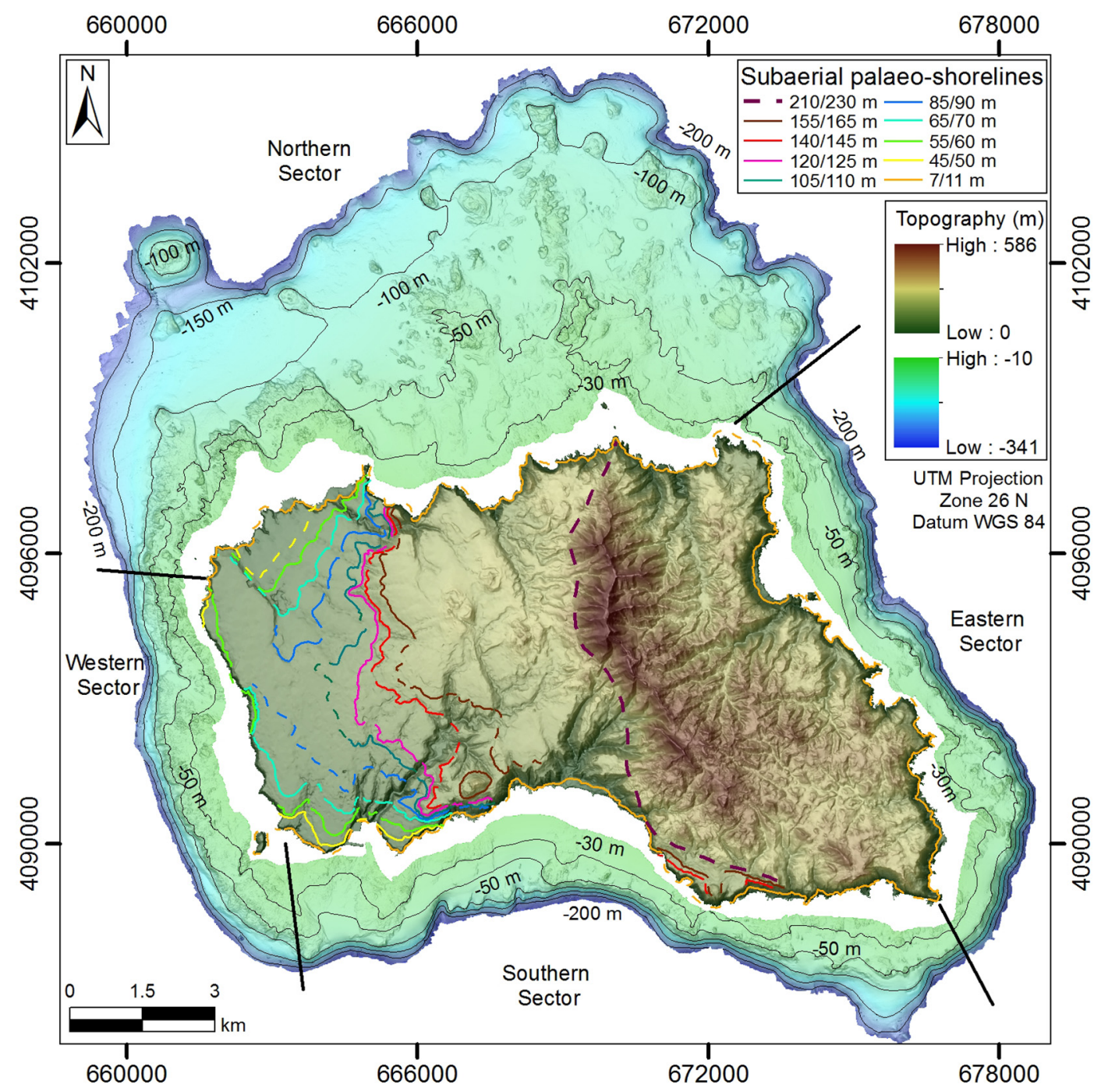

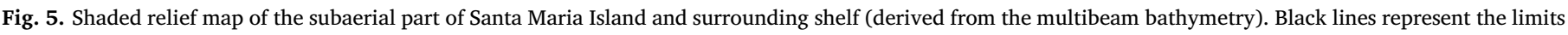

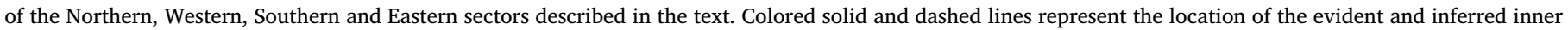

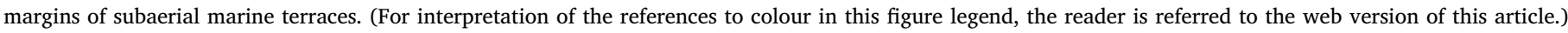
Modified after Ramalho et al. (2017).

almost the entire northern shelf sector and on the summit of the pillow cone of Baixa do Ambrósio (blue line in Figs. 7 10, 1214 and 2ESM, 4ESM 7ESM). This terrace is up to $\sim 2 \mathrm{~km}$ wide (average width of $\sim 880$ $\mathrm{m}$, Table 2ESM) along the easternmost portion of the northern shelf. To the west (corresponding to the rocky blocks offshore Ponta dos Frades, Fig. 7) its expression is markedly reduced, having the same discontinuous nature as the terrace at $-40 /-50 \mathrm{~m}$. Despite being less extensive and being partly eroded by small landslides, the same terrace is evident on the western shelf sector to the north of the WNW ESE trending tectonic lineament offshore Campo Grande (average width of $100 \mathrm{~m}$, Fig. 8 and Table 2ESM). South of this lineament it is almost absent. Along the southern shelf sector, this terrace is interrupted by tectonic lineaments, being mainly developed offshore Ponta do Castelo $(\sim 300 \mathrm{~m}$ wide, Fig. 9). Here the average width is about $90 \mathrm{~m}$ (Table 2ESM). Along the eastern shelf sector, the terrace occurs discontinuously (Fig. 10) and is $\sim 100 \mathrm{~m}$ wide on average (Table 2ESM).

\subsubsection{Terrace at $-85 /-90 m$}

This terrace has an inner edge located at $-85 /-90 \mathrm{~m}$ (yellow line in Figs. 7, 9, 10, 1ESM, 4ESM 7ESM) being wider in the northern shelf sector (Fig. 7), where it can attain widths of $\sim 1 \mathrm{~km}$ (over $500 \mathrm{~m}$ on average, Table 2ESM). Along the rocky outcrops offshore Ponta dos Frades, it is also interrupted (like the two previous terraces) by linea ments. Apart from the northern shelf sector, this terrace is also preserved in places along the southern sector (average width of $50 \mathrm{~m}$, Table 2ESM), where it is also partly interrupted by tectonic lineaments (Fig. 9). Along the eastern sector it occurs sporadically with an average width of $50 \mathrm{~m}$ (Fig. 10 and Table 2ESM).

\subsubsection{Terrace at $-100 /-110 \mathrm{~m}$}

This terrace has an inner edge located at $-100 /-110 \mathrm{~m}$ (purple line in Figs. 7 9, 11 13, 2ESM, 4ESM 6ESM) and the greatest width along the northern sector (average $800 \mathrm{~m}$, Table 2ESM), which pro gressively decreases from west to east. This terrace has also been de tected around Baixa do Ambrósio, even if it is narrower (com monly < $50 \mathrm{~m}$ ) (Fig. 7). The inner edge also appears to be affected by the faults seen offshore Anjos and Baía da Cré (Fig. 7), although less distinctively when compared with other terraces. Along the western and southern shelf sectors the same terrace is observed in narrow strips where the shelf edge is deeper (Figs. 8, 9, and 4ESM 6ESM) and has average widths of 70 $\mathrm{m}$ and $50 \mathrm{~m}$, respectively (Table 2ESM). In these sectors, several landslide scars make the terrace laterally discontinuous 


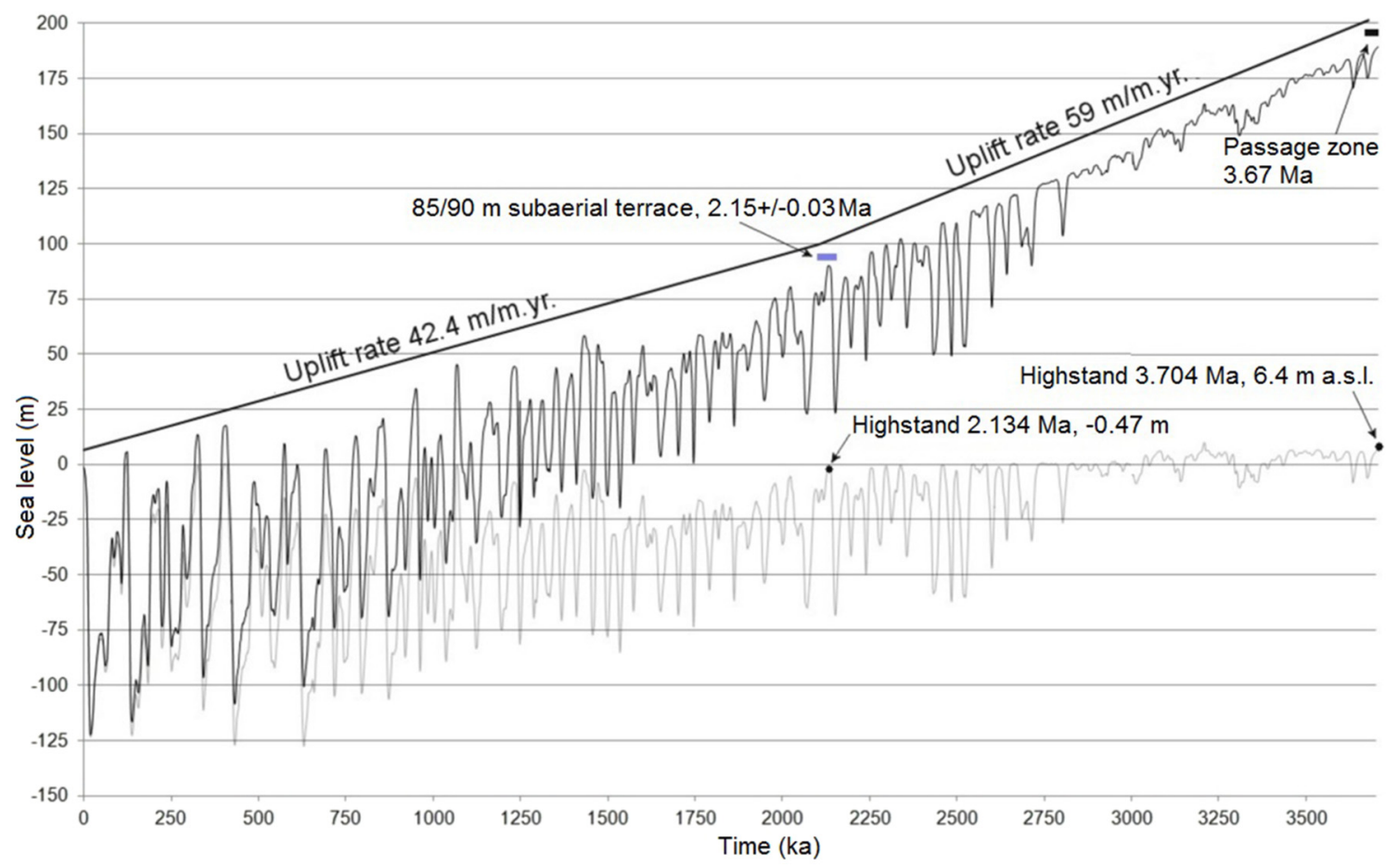

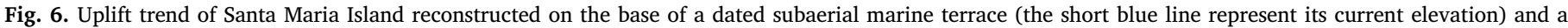

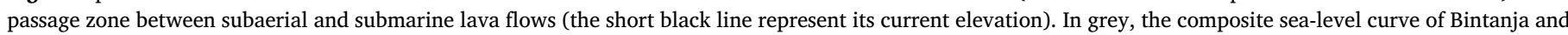

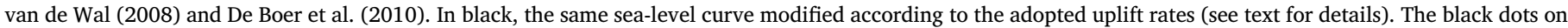

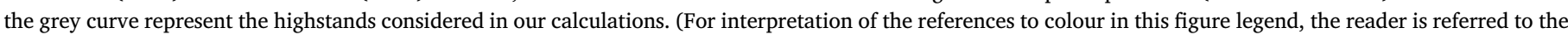
web version of this article.)

(Figs. 8 and 9). This terrace is not present on the eastern shelf sector (Fig. 10).

\subsubsection{Terrace at $-120 /-140 \mathrm{~m}$}

This is the deepest submerged terrace identified on the shelf, with the inner edge located between -120 and $-140 \mathrm{~m}$ (red line in Figs. 79 , 11, 13, 1ESM, 2ESM, 4ESM 6ESM). Along the eastern and central portions of the northern shelf sector it is characterized by a patchy distribution, whilst to the west it widens (offshore Anjos to Baía do Mar da Barca in Fig. 7), being characterized by a sub horizontal surface and an evident inner edge (Fig. 1ESM). This submerged terrace has also been detected at Baixa do Ambrósio (Fig. 7). In the northern sector it has an average width of $300 \mathrm{~m}$ (Table 2ESM), whereas it is marked by narrow and discontinuous strips (average widths of $\sim 100 \mathrm{~m}$ ) affected by small scale landslide scars on the western shelf sector (Fig. 8). Along the southern shelf sector, it is almost absent apart from a sub horizontal surface, with an inner edge at $\sim-120 \mathrm{~m}$. The terrace has an average width of $\sim 130 \mathrm{~m}$ (Table 2ESM) whilst its maximum width is $\sim 300 \mathrm{~m}$ offshore Ponta do Castelo (Figs. 9 and 13). This terrace is also absent along the eastern sector (Figs. 10 and 14).

\subsection{Correlation of marine terraces with sea level oscillations}

Following the approach described in Section 3.3, and taking into account the associated limitations and uncertainties, a possible time frame for the formation of each marine terrace is here proposed (Fig. 15). It was assumed that the subaerial terraces were preserved when uplift quickly carried them above the level of wave action (see Trenhaile, 2002, 2014). Because of uplift, only the most recent sea level stands could be responsible for the formation of the submerged terraces. The results of our reconstruction (Fig. 15) imply that the uppermost subaerial terrace $(210 / 230 \mathrm{~m}$ a.s.l.) recognized by Ramalho et al. (2017) has no match with sea level stands younger than 3.5 Ma. This is largely a modelling artifact given that we anchored the formation of the
Pico Alto lava deltas to a particular highstand at 3.704 Ma. Moreover, the $210 / 230 \mathrm{~m}$ terrace was marked by Ramalho et al. (2017) with a high uncertainty because its morphologic imprint on the island is not clearly recognizable. Given these limitations, we will focus our analysis on terraces that are located below the passage zone of Pico Alto's lava deltas (at approximately $200 \mathrm{~m}$ ). These terraces can be found down to $45 / 50 \mathrm{~m}$ in elevation, after which the island is cliff bounded, with no visible terraces excepting the $711 \mathrm{~m}$ terrace, which is preserved in places (see Fig. 5). Accordingly, we propose that the subaerial marine terraces (with the exception of the lowest and highest) were formed between $3.436 \mathrm{Ma}$ to $1.065 \mathrm{Ma}$ BP (Fig. 15 and Table 1ESM). The lowest subaerial terrace (7 $11 \mathrm{~m}$ ), despite being exclusively attributed to MIS 5e by Ramalho et al. (2017) on the basis of existing sedimentary deposits, according to our model could have been formed and subse quently modified from 1.749 Ma to $121 \mathrm{ka}$ (a period of $1.628 \mathrm{~m} . \mathrm{yr}$, Table 1ESM). Our reconstructions also suggest that, on account of the reduction of uplift trend but also because of the gradual increase in the amplitude of the sea level oscillations, as well as a decrease in their frequency, from $2.8 \mathrm{Ma}$ to the present, the possible age interval during which sea level was able to carve and modify these terraces also in creased (Fig. 15). Using the same approach, the formation and sub sequent development of the submerged terraces probably took place in various stages between $1.122 \mathrm{Ma}$ and $12.1 \mathrm{ka}$, with the deepest sub merged terrace $(-120 /-140 \mathrm{~m})$ being only affected by the lowstand at $19.8 \mathrm{ka}$ (MIS 2; Table 1ESM).

A parameter to consider in these reconstructions is also the effective time that sea level was at a particular elevation to form a terrace (within $\mathrm{a} \pm 5 \mathrm{~m}$ uncertainty; see Table 1ESM). This is different from the possible age interval during which sea level passed through each terrace elevation i.e., considering also the combined effects of uplift and glacioeustatic oscillations. Whilst the possible age interval for the formation of a terrace provides us with a maximum and minimum age for that terrace, the effective time quantifies the actual amount of time sea level spent at that particular elevation. This information provides the total 


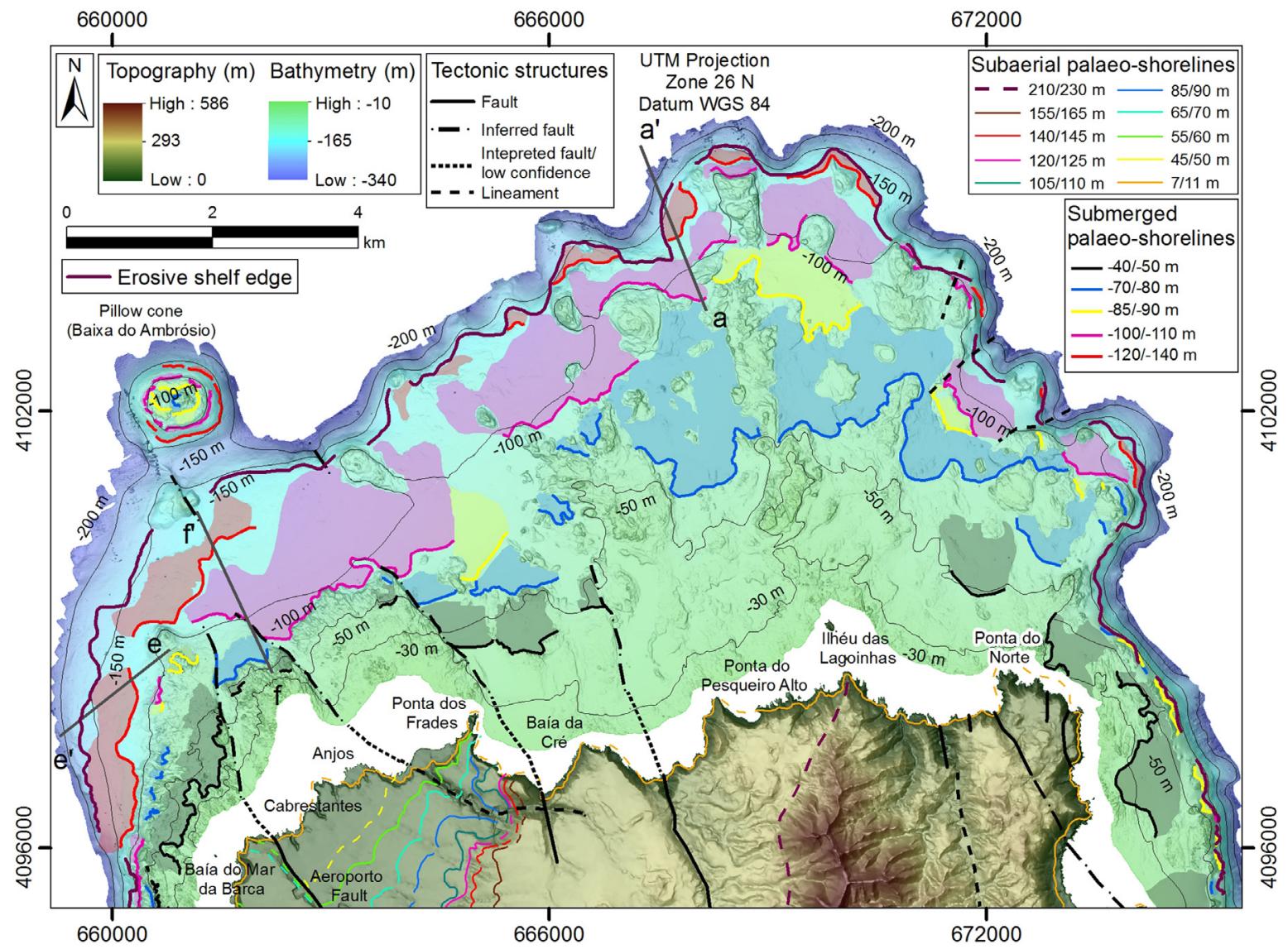

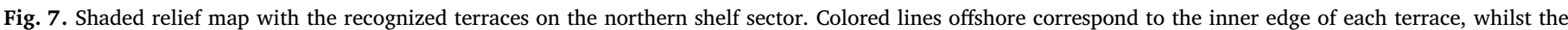

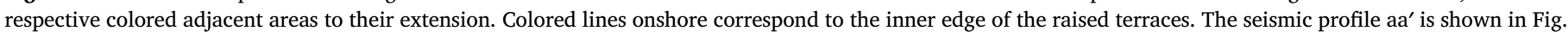

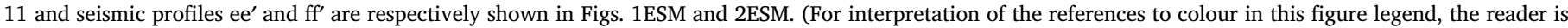
referred to the web version of this article.)

amount of time a terrace was effectively exposed to active wave erosion during all the cycles included within the possible age interval. For in stance, the effective time during which sea level was at the elevation of the inner margin of the $45 / 50 \mathrm{~m}$ raised terrace ( $305 \mathrm{k} . \mathrm{yr}$ ) is estimated to be similar to that of the $155 / 165 \mathrm{~m}$ terrace (318.7 k.yr) although the possible age interval for their formation is very different (respectively $1.460 \mathrm{~m}$.yr, i.e. between $2.525 \mathrm{Ma}$ and $1.065 \mathrm{Ma}$, and $373 \mathrm{k} . \mathrm{yr}$, i.e. between $3.436 \mathrm{Ma}$ and $3.063 \mathrm{Ma}$, Table 1ESM).

\section{Discussion}

Several geological and oceanographic factors such as uplift/subsidence rates, local changes in wave regime, shelf gradients, differential resistance to erosion, amplitude of sea level oscillations and stillstand duration influence the formation and preservation of marine terraces (Trenhaile, 2002, 2014; Ramalho et al., 2013). It is thus difficult to isolate, in quantitative terms, the contribution of each of these factors in controlling the spatial distribution of the observed terraces.

Our correlation between the present day position of marine terraces and relative sea level for the last $3.5 \mathrm{Ma}$ allowed us to suggest a likely timing (or age interval) of formation for each subaerial and submerged terrace. Despite the many sources of uncertainty in this approach such as uncertainties in the adopted eustatic curve (particularly before the last $3 \mathrm{Ma}$ ) and in uplift rates, along with the fact that we did not in corporate any effects of glacio isostatic adjustment it constitutes a first order approximation from which useful insights can be derived concerning the generation, destruction, and preservation of marine terraces along an uplifting landmass, throughout a considerable period of time (3.5 m.yr) and under the effects of multiple glacio-eustatic cycles. This integrated onshore/offshore approach has been rarely adopted but constitutes the basis for a more complete, holistic comprehension of how long term relative sea level change interacts with landmasses to form distinctive coastal and nearshore morphologies such as subaerial and submerged terrace staircases.

\subsection{Subaerial terraces}

According to Ramalho et al. (2017), the interplay between exposure to the dominant wave direction (from the western quadrant, i.e. the windward side) and a favorable lithological/stratigraphical framework (i.e. the softer Touril sequence and the gently dipping contacts between this units and underlying Anjos and overlying Pico Alto volcanic edifices) in the western half of Santa Maria, enhanced coastal retreat and formed a wide and gently sloping terraced morphology, under the combined action of uplift and glacio isostatic oscillations. We agree with this model, which offers a simple enough explanation for the is land asymmetry, being in tune with the local lithological, structural, and oceanographic conditions. Our analysis, however, suggests that the effective time of formation is also an important factor contributing to the generation of the terraced morphology in this part of the island, and to the greater width of the terraces now located between $50 \mathrm{~m}$ and $120 \mathrm{~m}$ in elevation.

Our reconstructions suggest that subaerial terraces at Santa Maria are most probably polygenic because uplift rates were low enough to expose each terrace to the passage of several sea levels (Fig. 15). As such, these terraces were affected by wave erosion during multiple cycles of rising and falling sea level (Fig. 15, Table 1ESM). According to our calculations, the effective time that each terrace was exposed to 


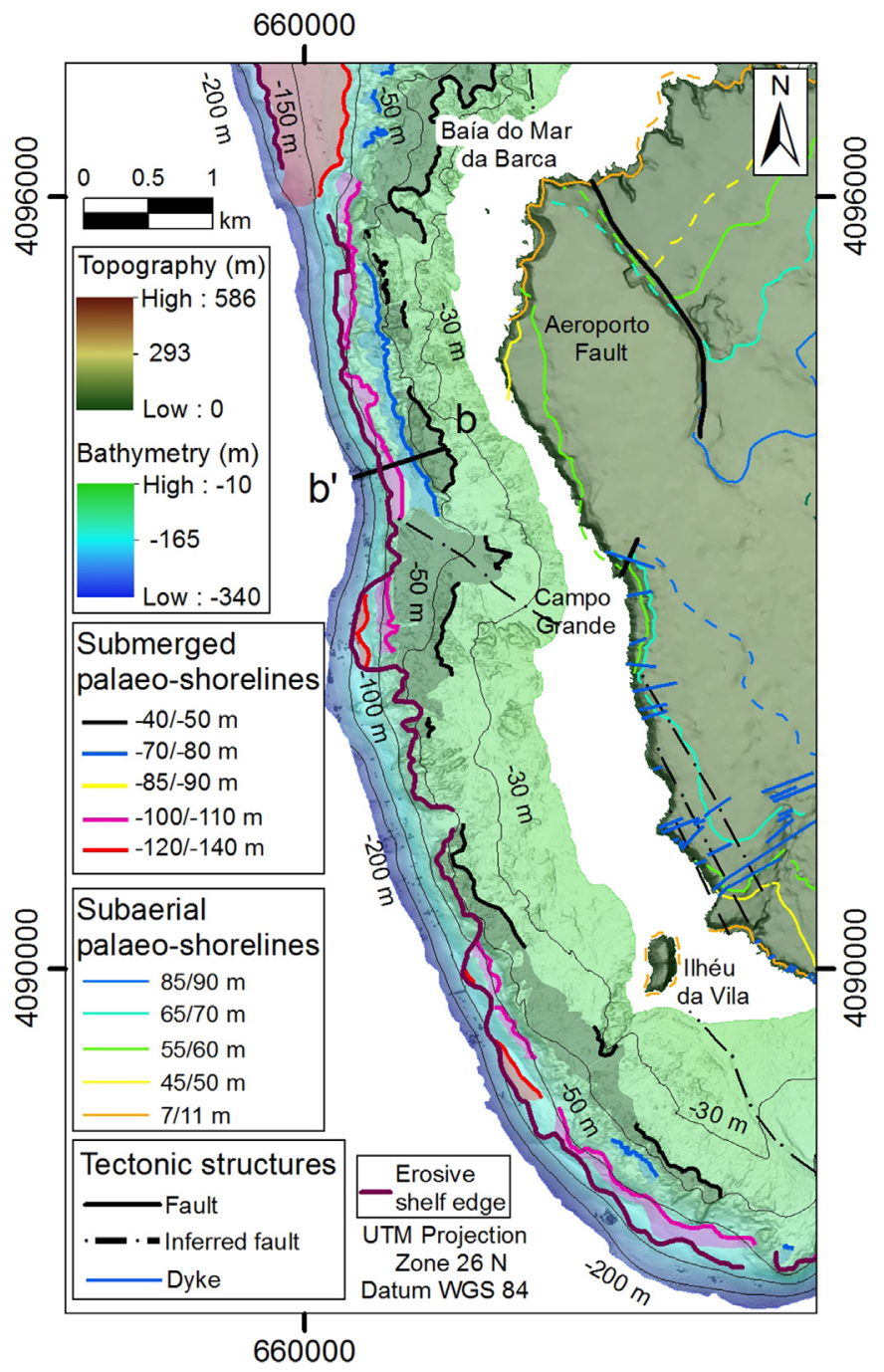

Fig. 8. Shaded relief map with the recognized terraces on the western shelf sector. Legend is the same as in Fig. 7. The seismic profile bb' is shown in Fig. 12. (For interpretation of the references to color in this figure, the reader is referred to the web version of this article.) wave erosion with passing sea level spans from $\sim 140$ to $\sim 319 \mathrm{k} . \mathrm{yr}$, much more than the average duration of a single highstand or stillstand. A possible relationship exists between terrace width and effective time, e.g. wider terraces were subjected to marine erosion for longer time periods. The plot between terrace width vs effective time shown in Fig. 16 (see also Tables 1ESM and 3ESM) suggests a positive correlation between these two parameters, with terrace width increasing proportionally to the effective time they have been exposed to sea level. Notable exceptions to this trend include the $105110 \mathrm{~m}$ and $155165 \mathrm{~m}$ terraces, which are considered outliers for different reasons. The 105 $110 \mathrm{~m}$ terrace coincides with the bulk of the softer Touril sequence (allowing for enhanced coastal retreat in a shorter period of time) and therefore it is not surprising it deviates from this relationship. Why the $155165 \mathrm{~m}$ terrace is relatively narrow despite the fact it was probably exposed for a longer effective time (Table 3ESM) is more difficult to explain. However, a possible explanation lies in the fact that this terrace, being one of the oldest, has suffered considerable topographic decay since its formation.

A peculiar fact about Santa Maria is that it does not exhibit any well developed raised marine terraces below $4550 \mathrm{~m}$ in elevation, with the exception of the $711 \mathrm{~m}$ terrace, attributed to MIS 5e (Ramalho et al., 2013; Ávila et al., 2015; Ramalho et al., 2017). In between these elevations, only rare and poorly developed wavecut notches can be observed (Ramalho et al., 2017). In our view, the combined effect of two factors might have contributed to this absence. One is related to the fact that in the last $1 \mathrm{~m} . y \mathrm{r}$ the frequency of the glacio eustatic oscillations started to be dominated by the longer $100 \mathrm{k} . y r$ (Miller et al., 2005), reducing the effective time for erosion at each elevation over this whole period, as highstands/stillstands were fewer when compared to the Late Pliocene and Early to Mid Pleistocene. During the latter period, the amplitude of glacio eustatic oscillations was lower and their frequency was dominated by the $41 \mathrm{k} . y r$ cycles, implying more frequent passages of sea level at each elevation (resulting in longer effective times for erosion). The second effect could be related to a slowdown in uplift rates perhaps a slowdown even more dramatic than we modelled in Fig. 15 during which terrace preservation would be significantly in hibited, with erosion at each subsequent highstand erasing previous terraces and contributing to the maintenance of steep plunging cliffs. This reduction in uplift rates is, in fact, supported by the position of MIS 5e deposits and notches, which indicate a relative sea level at $711 \mathrm{~m}$, a position just slightly above the expected elevation for MIS $5 \mathrm{e}$ in the area (Bintanja and van de Wal, 2008). Our reconstructions suggest that the $711 \mathrm{~m}$ erosive surface is probably polygenic, notwithstanding the fact

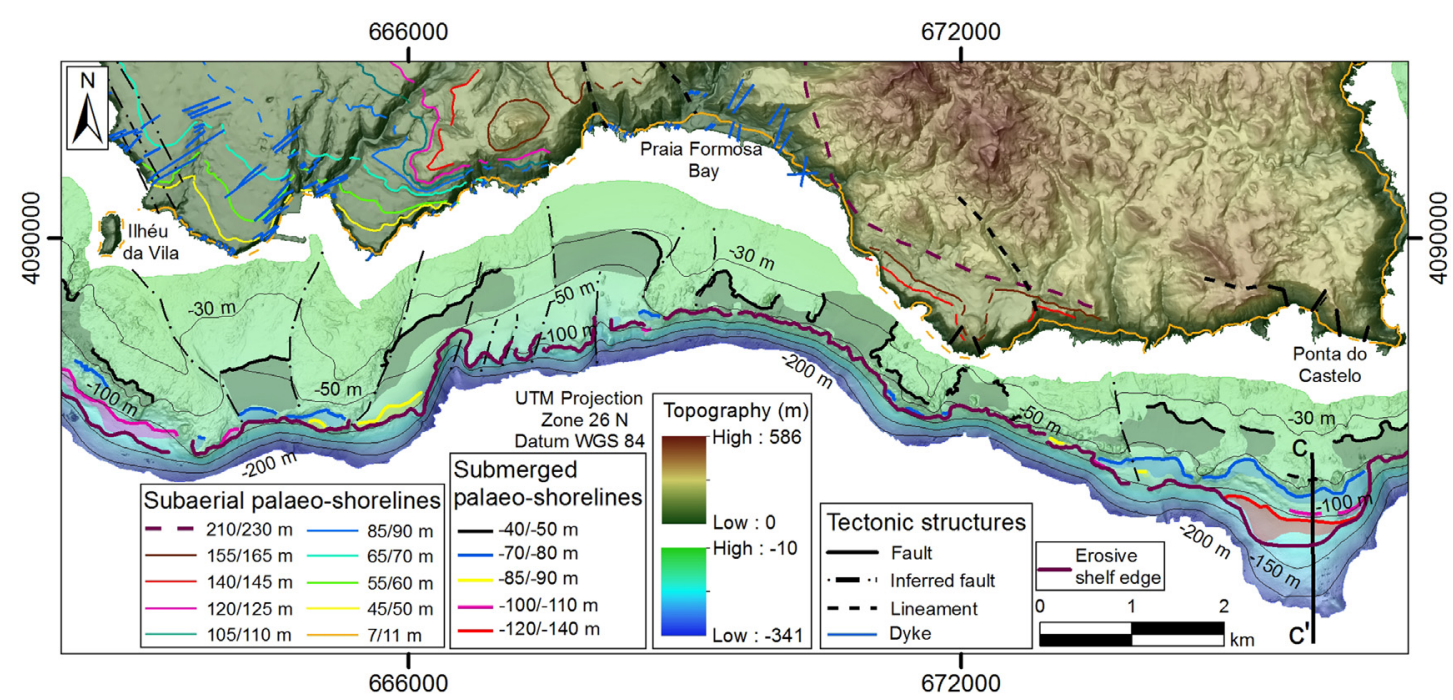

Fig. 9. Shaded relief map with the recognized terraces on the southern shelf sector. Legend is the same as in Fig. 7. The seismic profile cc' is shown in Fig. 13. (For interpretation of the references to color in this figure, the reader is referred to the web version of this article.) 


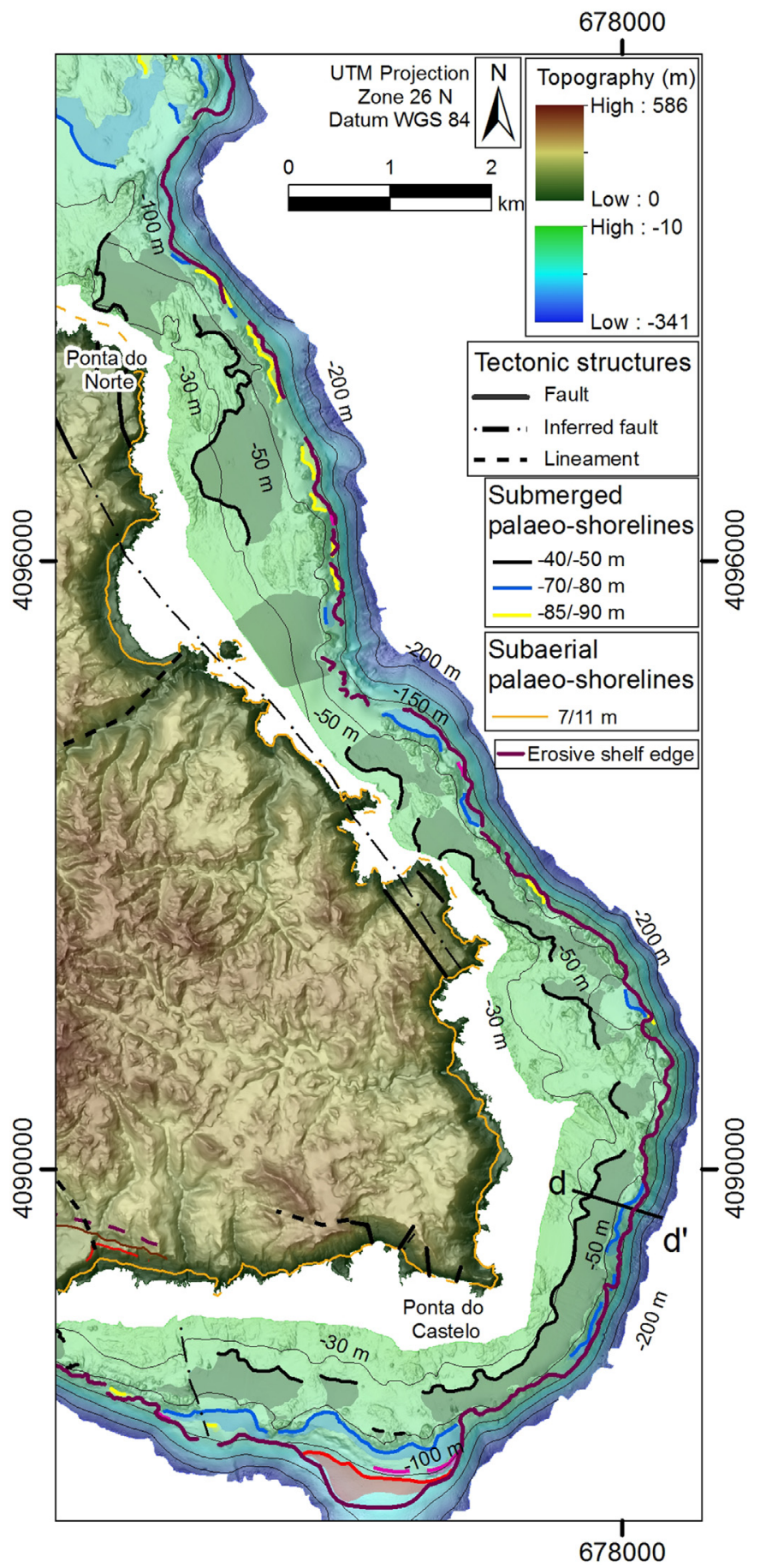

Fig. 10. Shaded relief map with the recognized terraces on the eastern shelf sector. Legend is the same as in Fig. 7. The seismic profile dd' is shown in Fig. 14. (For interpretation of the references to color in this figure, the reader is referred to the web version of this article.)

that MIS 5e deposits can be found resting on this surface (Callapez and Soares, 2000; Ávila et al., 2008; Ávila et al., 2015; Ramalho et al., 2017). Fig. 15 shows that in the last 1.7 m.yr multiple stillstands could have effectively contributed to the erosion of such a surface, although this terrace had maintained a significant morphological and depositional imprint by the Last Interglacial. This highstand was thus re sponsible for planating even further an already existing terrace (carved during previous cycles), being also responsible for the deposition of fossiliferous beach deposits that can nowadays be found preserved at several sites along this palaeo shoreline.

\subsection{Submerged terraces}

The distribution and characteristics of the submerged terraces likely result from the interaction of several factors, which contributed to their formation and preservation or destruction, depending on their position. Particularly, the width of the submerged terraces is thought to be controlled by the carved lithology, shelf gradients, water depth at the time of formation, frequency and amplitude of relative sea level changes (Trenhaile, 2014).

Our data show that submerged terraces (except for the shallowest terrace at $-40 /-50$ ) are much wider and better preserved in the northern shelf sector than in the other sectors. Moreover, this shelf sector is the only one exhibiting the complete set of submerged marine terraces. This situation can be explained by the low shelf gradients characterizing the northern shelf, which likely allowed for the development of much wider terraces, despite the greater wave attenuation induced by the lower gradients (Trenhaile, 2014). Lithological and structural factors probably also contributed to a greater width of terraces in this sector. The profusion of softer pyroclastic structures due to numerous cinder/scoria cones, for instance, may have allowed faster marine erosion and enhanced coastal retreat, resulting in wider terraces. Differently, the poor development or even absence of deeper terraces on the other shelf sectors (Table 2ESM) could be related to the steeper pre existing shelf gradients on harder effusive substrates, which precluded the development and preservation of wide terraces. Previous studies (e.g. Anderson et al., 1999; Trenhaile, 2014) suggested, in fact, that terrace destruction due to marine erosion during rapidly rising sea levels (such as during glacial terminations) is more effective when shelf gradients are steeper. In addition, it should be considered that deeper terraces could have been erased by retrogressive (landward) erosion of the shelf edge by small scale mass wasting, as suggested by the morphology of the shelf edge along the western, southern and eastern sectors (Figs. 8, 9 and 10). Effectively, along the western and southern sectors, the deepest terraces are only present where the shelf edge is preserved in deeper waters. In the eastern sector only shallow and midterraces are present, because the shelf edge is always shallower than $-100 \mathrm{~m}$. Due to its geological structure composed of eastward dipping steep foresets of pillow lavas and hyaloclastites of the Pico Alto Volcanic Complex this sector of the shelf is more prone to landsliding and therefore terraces are less likely to be preserved, particularly at greater depths (Ramalho et al., 2013; Ramalho et al., 2017).

We have also verified the possible relationship between submerged terrace width vs effective time of erosion (Fig. 16 and Table 2ESM). The data distribution is more scattered than for subaerial terrace, even if a slightly positive correlation can be visually observed in the plots. This larger scatter can be related to the fact that submerged terraces have been affected by more cycles of erosional modification during subsequent periods of rising and falling sea level, being thus characterized by a less distinctive shape than subaerial terraces (Trenhaile, 2014). Unsurprisingly, due to uplift (even if very slow) and increasing eustatic amplitudes in the Late Quaternary, the $-40 /-50 \mathrm{~m}$ terrace is gen erally the widest, except for the northern sector (Figs. 15 and 16). This surface is polygenic, and results from recurrent erosion over a greater time period than other submerged terraces (Fig. 15 and Table 2ESM). Conversely, we do not have a simple explanation for its lower width in the northern shelf sector with respect to the deeper terraces; perhaps the lithology where this terrace was carved was harder in the northern sector. More generally, it is also difficult to explain the similar range of width observed for this terrace in the different sectors, unless to imagine that the controlling factors for its genesis (shelf gradients, water depths and so on) or their interplay were quite constant around Santa Maria at the time of its formation.

\subsection{Tectonic control on marine terraces}

Faulting at Santa Maria clearly affects the subaerial terraces from 


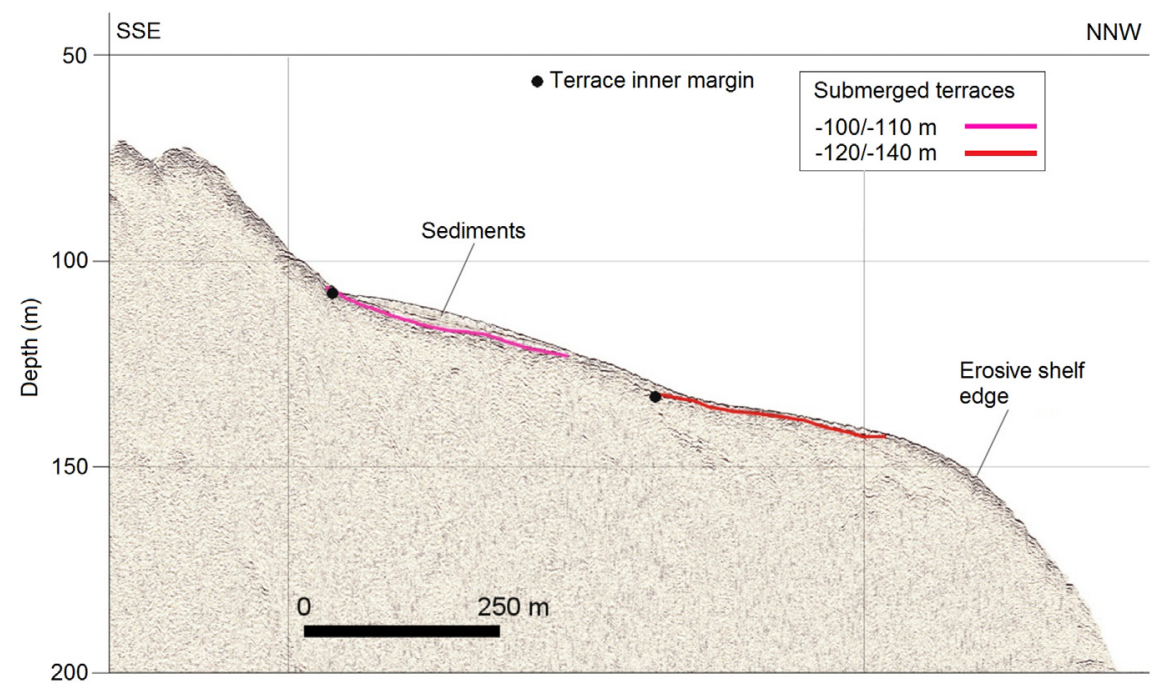

Fig. 11. Boomer seismic profile aa' showing the shelf morphology off the northern sector of Santa Maria. Location of the seismic profile in Fig. 7. (For interpretation of the references to color in this figure, the reader is referred to the web version of this article.)

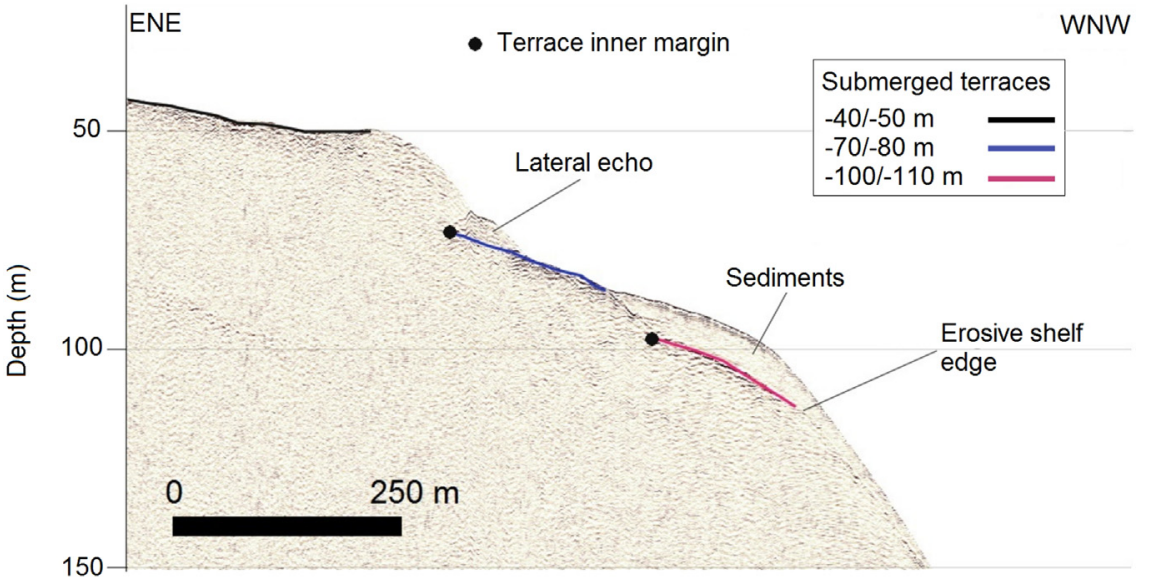

Fig. 12. Boomer seismic profile bb's showing the shelf morphology off the western sector of Santa Maria. Location of the seismic profile in Fig. 8. (For interpretation of the references to color in this figure, the reader is referred to the web version of this article.)

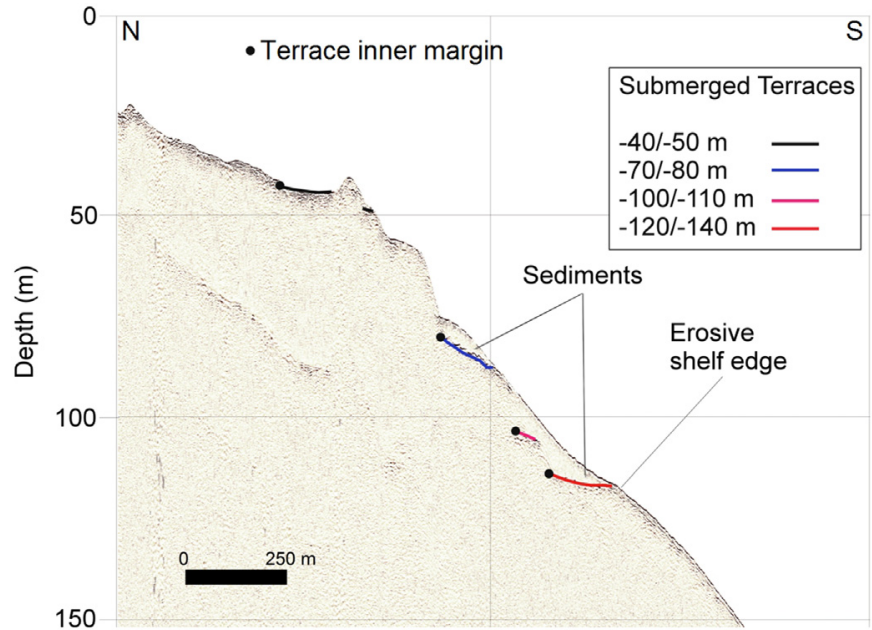

Fig. 13. Boomer seismic profile $\mathrm{cc}^{\prime}$ showing the shelf morphology off the southern shelf sector of Santa Maria. Location of the seismic profile in Fig. 9.(For interpretation of the references to color in this figure, the reader is referred to the web version of this article.)

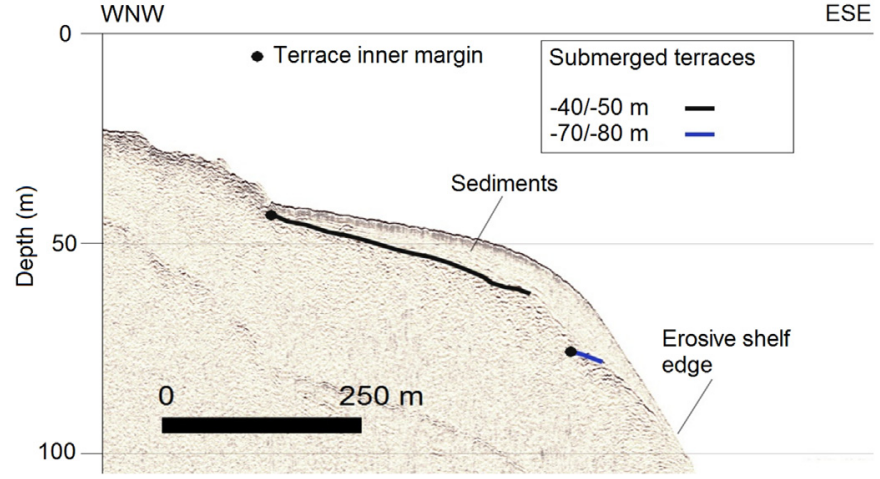

Fig. 14. Boomer seismic profile dd' showing the shelf morphology off the eastern shelf sector of Santa Maria. Location of the seismic profile in Fig. 10.(For interpretation of the references to color in this figure, the reader is referred to the web version of this article.)

the shallowest one up to at least the $85 / 90$ m terrace, which means that these faults could have been activated sometime after $\sim 2.7 \mathrm{Ma}$. However, this might have started before, but due to the subaerial erosion and sediment covering of the faults it is impossible to verify. Since the faults also affect the distribution and geometry of the submerged 


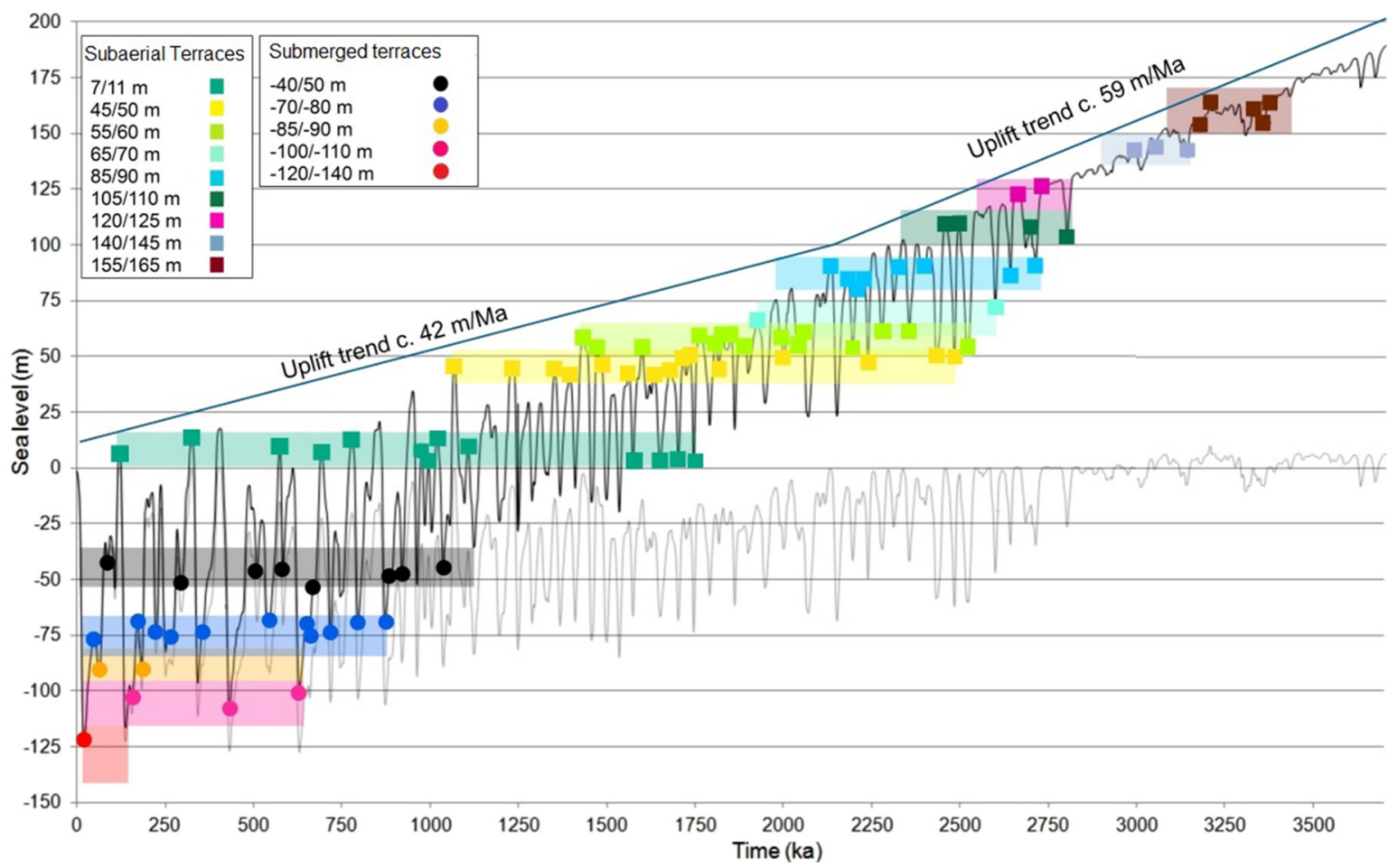

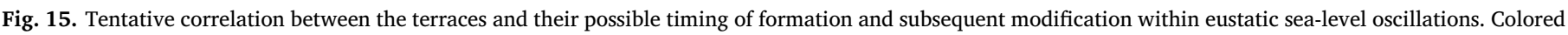

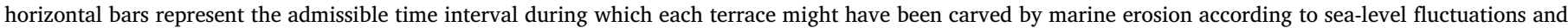

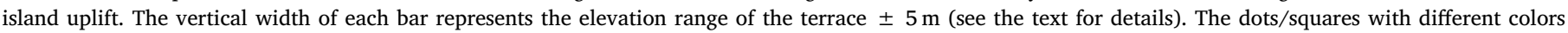

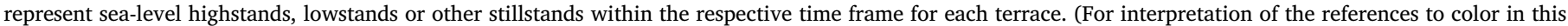
figure, the reader is referred to the web version of this article.)

terraces (at least down to the $-85 /-90 \mathrm{~m}$ terrace), according to our model these faults might have been active up to at least $693 \mathrm{ka}$ ago, or $15 \mathrm{ka}$ at the latest. In detail, on the northern shelf sector the shallowest terrace $(-40 /-50 \mathrm{~m})$, together with the $-70 /-80 \mathrm{~m}$ and -85 / - $90 \mathrm{~m}$ terraces, are all affected by several NW SE faults, located between Baía do Mar da Barca and Baía da Cré (see Fig. 7). These faults extend inland, where they displace the subaerial terraces up to $90 \mathrm{~m}$ in elevation, as with the "Aeroporto fault", or at Baía da Cré. The tectonic structure in this sector suggests a compartmentalization of the volcanic edifice in grabens and semi grabens, where blocks with a relative downthrown movement experienced greater degrees of coastal retreat, allowing also for the formation of depocenters where marine sedimentation occurred. A similar situation can be observed along the deepest part of the shelf at the southern sector (Fig. 9). Here, terrace geometry and distribution are somewhat controlled by several tectonic lineaments (roughly oriented NNE SSW) that may either correspond to faults, or to dikes that served as limiting barriers to erosion and sedimentation. The NW SE lineament offshore Campo Grande, in the western shelf sector (Fig. 8), also limits the $-70 /-80 \mathrm{~m}$ terrace to the south of this lineament. These features show that local vertical tectonics played an important role in the development of submerged marine terraces, a role that needs further investigation. However, these local effects do not influence the overall depth ranges of marine terraces.

\subsection{Terrace formation and preservation}

As far as we know, Santa Maria is the only reefless volcanic island that has submerged terraces mapped with high detail. Most of the studies about terraces on volcanic islands are from reefal settings and are almost exclusively off Hawaii (e.g., Campbell, 1986; Faichney et al., 2010). Terraces in reef settings are mostly constructional in origin and hence they are of little utility for a comparison with our study. Nevertheless, some inferences can be made based on modelling of erosional terraces (Trenhaile, 2002, 2014) and the geological record of raised and submerged terraces in other settings.

Raised terraces in Santa Maria are moderately well preserved despite their relatively old age (3.436 1.065 Ma). However, terraces developed on islands and on relatively narrow landmasses tend to be better preserved because the length of the streams is limited and so is the erosion of the landscape (Anderson et al., 1999). Two contrasting hypotheses regarding the formation/preservation of the terraces have been found in the literature. According to Pedoja et al. (2014) coastal staircase sequences are present mainly in areas where apparent uplift rates are very low to moderate, because sea level must remain stationary long enough to allow for the formation of these features. Their compilation of subaerial terraces in hotspot settings shows that these occur on islands with average uplift rates of $0.01 \mathrm{~mm} / \mathrm{yr}$. However, modelling by Trenhaile $(2002,2014)$ suggest that only rapid uplift rates are able to preserve terraces, otherwise these are removed by erosion and cliff retreat during periods following high, interglacial sea level. Trenhaile (2014) considers $0.02 \mathrm{~mm} / \mathrm{yr}$ as slow uplift rates and $0.1 \mathrm{~mm} /$ yr as fast. Our data agree with the model presented by Trenhaile (2014). In fact, estimated uplift rates for Santa Maria $(0.042 / 0.059 \mathrm{~mm} / \mathrm{yr})$ fall between those two values of Trenhaile (2014), which might explain why the terraces are relatively well preserved.

As for submerged terraces, modelling by Trenhaile (2014) suggests that very narrow terraces form on uplifting coasts (Fig. 6 of Trenhaile, 2014). According to this author, this is because submerged terraces are preferentially formed during lowstands and are subsequently modified (or even eliminated) during periods of rising and falling sea as they are uplifted. Our observations support, however, the preservation of different orders of submerged terraces on the shelf of Santa Maria. Not surprisingly, the average width (Table 3ESM) of the submerged terraces of Santa Maria is smaller (normally $<200 \mathrm{~m}$ if we exclude the northern sector) than the width of the subaerial terraces (300 $500 \mathrm{~m}$ ). A likely explanation lies in the fact, already discussed above, that submerged 


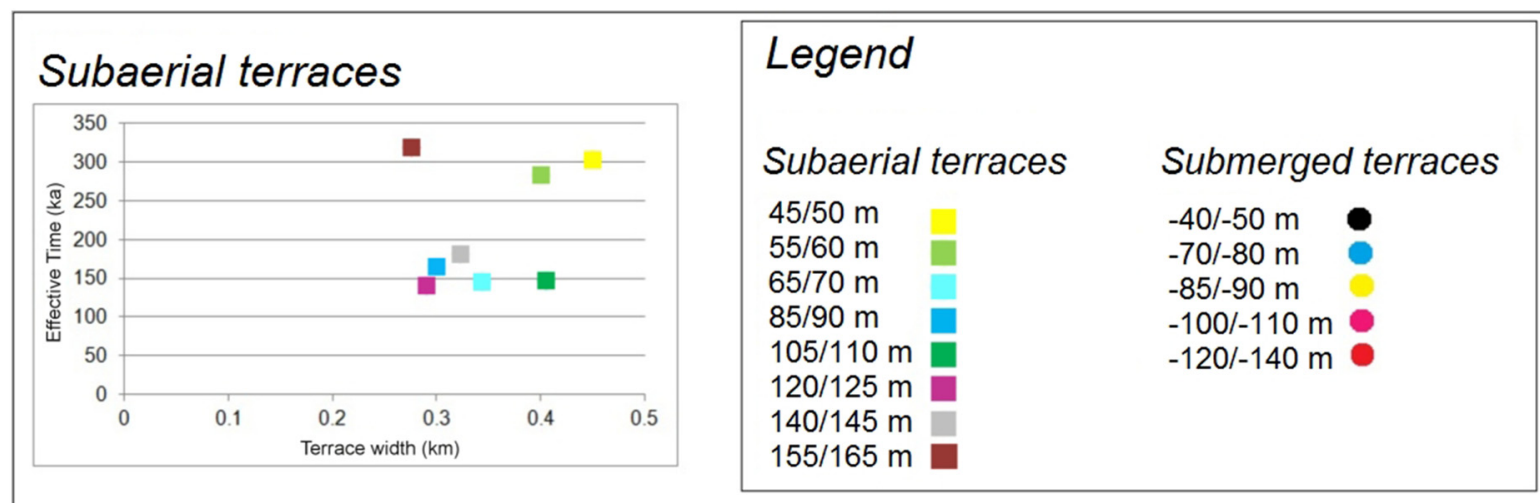

\section{Submerged terraces}
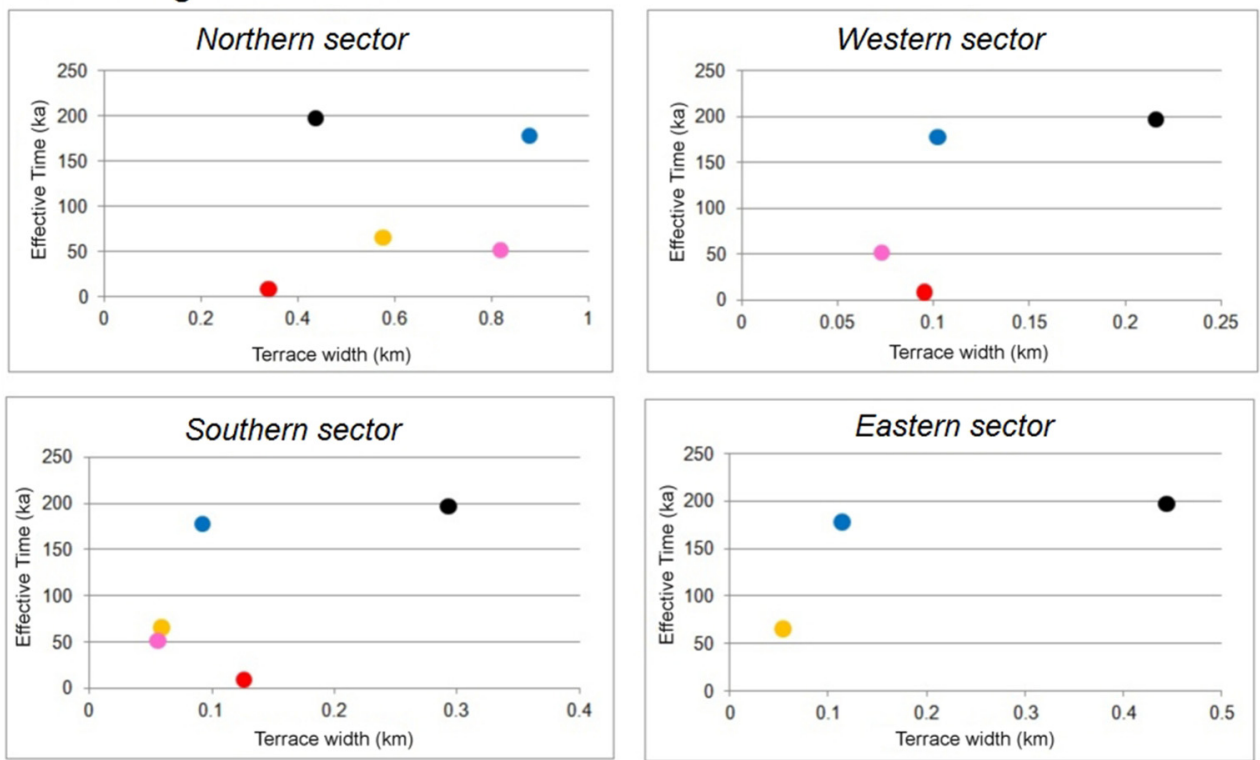

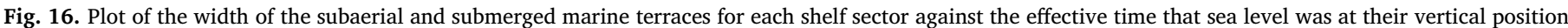

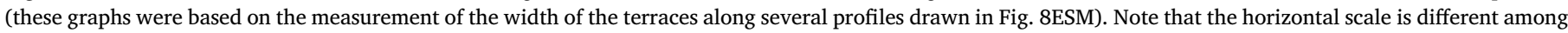
shelf sectors.

terraces here bear the strong imprint of sea level changes with much higher amplitude and lower frequency in the late Quaternary than the raised terraces formed in early middle Quaternary (Fig. 15). According to Trenhaile (2014) the scale of sea level oscillations has an important effect on shelf width, which increases with increasing eustatic amplitude on uplifting landmasses. The fact that submarine terraces are systematically eroded by passing sea level as the shelf widens, also contributes to a final morphology in which clearly preserved terraces are apparently not as wide as subaerial terraces.

\section{Conclusions}

In this study we analyzed for the first time the possible correlation between the formation of the subaerial and submerged terraces with known sea level changes, on a reefless volcanic island setting. Our approach, including the integration of newly available high resolution marine geophysical data with detailed onshore field studies, allowed us to:

- recognize five sets of submerged marine terraces located at different depths.

- better estimate the uplift rates for Santa Maria island, using two dated raised, subaerial palaeoshorelines and a composite sea level curve. Those rates were used to determine the possible age interval of formation of subaerial and submerged marine terraces, ranging from $3.436 \mathrm{Ma}$ to $12.1 \mathrm{ka} \mathrm{BP}$, being formed and later modified by more than one passage of sea level.

- analyze the controlling factors on the submerged marine terraces distribution. On low gradient, and consequently wider shelves, ter- races are more easily carved/preserved. Conversely, steeper shelf gradients facilitate the erosion of upper and older terraces by younger and deeper terraces in uplifting areas. better constraint the faulting activity at least to the $0.6932 .7 \mathrm{Ma}$ period, based on the offset experienced by subaerial and submerged terraces. Activity could have been more prolonged in time, but degradation of the subaerial terraces and lack of clear evidence on the submerged ones does not allow us to extend further that period. -propose an original and consistent reconstruction for the marine terraces formation at Santa Maria, notwithstanding the complex interplay between glacio eustatic oscillations, marine erosion, and island uplift.

Supplementary data to this article can be found online at https:// doi.org/10.1016/j.margeo.2018.09.002. 


\section{Acknowledgments}

The acquisition of multibeam bathymetry and seismic reflection profiles were funded by Fundação para a Ciência e a Tecnologia (FCT) through the PLATMAR project (PTDC/GEO GEO/0051/2014). The authors are grateful to the crew of R/V Arquipélago for all their help in the preparation and execution of the geophysical survey. R. Ramalho and R. Quartau acknowledge, respectively, their "Investigador FCT" contracts IF/01641/2015 and IF/00635/2015, funded by FCT. This study has been developed in the framework of the PhD thesis "Insular shelves as a tool for reconstructing the evolution of volcanic islands" (A. Ricchi, University of Bologna). We also sincerely acknowledge A. Trenhaile and an anonymous reviewer for useful suggestions.

\section{References}

Anderson, R.S., Densmore, A.L., Ellis, M.A., 1999. The generation and degradation of marine terraces. Basin Res. 11, 7-19. https://doi.org/10.1046/j.1365-2117.1999. 00085.x

Andrade, C., Trigo, R.M., Freitas, M.C., Gallego, M.C., Borges, P., Ramos, A.M., 2008 Comparing historic records of storm frequency and the North Atlantic Oscillation (NAO) chronology for the Azores region. The Holocene 18 (5), 745-754. https://doi. org/10.1177/0959683608091794.

Antonioli, F., Kershaw, S., Rust, D., Verrubbi, V., 2003. Holocene sea-level change in Sicily and its implications for tectonic models: new data from the Taormina area northeast Sicily. Mar. Geol. 3293, 1-19.

Ávila, S.P., Madeira, P., Da Silva, C.M., Cachão, M., Landau, B., Quartau, R., Martins, A.M., 2008. Local disappearance of bivalves in the Azores during the last glaciation. J. Quat. Sci. 23 (8), 777-785.

Ávila, S.P., Melo, C., Silva, L., Ramalho, R.S., Quartau, R., Hipólito, A., Cordeiro, R., Rebelo, A.C., Madeira, P., Rovere, A., Hearty, P.J., 2015. A review of the MIS 5e highstand deposits from Santa Maria Island (Azores, NE Atlantic): palaeobiodiversity, palaeoecology and palaeobiogeography. Quat. Sci. Rev. 114, 126-148. https://doi org/10.1016/j.quascirev.2015.02.012.

Bintanja, R., van de Wal, R.S., 2008. North American ice-sheet dynamics and the onset of 100,000-year glacial cycles. Nature 454 (7206), 869-872. https://doi.org/10.1038/ nature07158.

Blanchon, P., Jones, B., 1995. Marine-planation terraces on the shelf around Grand Cayman - a result of stepped Holocene sea-level rise. J. Coast. Res. 11 (1), 1-33 (PubMed PMID: WOS: A1995QG34200001).

Callapez, P., Soares, A.F., 2000. Late Quaternary marine mollusks from Santa Maria (Azores); paleoecologic and paleobiogeographic considerations. Ciências Terra (UNL)

14, 313-322.

Campbell, J.F., 1986. Subsidence rates for the Southeastern Hawaiian Islands determined from submerged terraces. Geo-Mar. Lett. 6 (3), 139-146.

Caputo, R., 2007. Sea-level curves: perplexities of an end-user in morphotectonic applications. Glob. Planet. Chang. 57 (3-4), 417-423.

Cas, R., Wright, J., 1987. Volcanic Successions. Modern and Ancient: A Geological Approach to Processes, Products and Successions. Chapman \& Hall, London. https://

doi.org/10.1007/978-94-009-3167-1. (528 pp.).

Casalbore, D., Falese, F., Martorelli, E., Romagnoli, C., Chiocci, F.L., 2017. Submarine depositional terraces in the Tyrrhenian Sea as a proxy for paleo-sea level reconstruction: problems and perspective. Quat. Int. 439, 169-180. https://doi.org/10. 1016/j.quaint. 2016.07.051.

Coulbourn, W.T., Campbell, J.F., Moberly, R., 1974. Hawaiian submarine terraces, can yons and quaternary history evaluated by seismic-reflection profiling. Mar. Geol. 17,

215-234.

De Boer, B., Van De Wal, R.S.W., Bintanja, R., Lourens, L.J., Tuenter, E., 2010. Cenozoic global ice-volume and temperature simulations with 1-D ice-sheet models forced by benthic 180 records. Ann. Glaciol. 51 (55), 23-33.

De Guidi, G., Monaco, C., 2009. Late Holocene vertical deformation along the coast of Pantelleria Island (Sicily Channel, Italy). Quat. Int. 206, 158-165. Faichney, I.D.E., Webster, J.M., Clague, D.A., Paduan, J.B., Fullagar, P.D., 2010. Unraveling the tilting history of the submerged reefs surrounding Oahu and the MauiNui Complex, Hawaii. Geochem. Geophys. Geosyst. 11 (7), Q07002.

Ferranti, L., Antonioli, F., Mauz, B., Amorosi, A., Dai, Pra G., Mastronuzzi, G., Monaco, C., Orrù, P., Pappalardo, M., Radtke, U., Renda, P., Romano, P., Sansò, P., Verrubbi, V., 2006. Markers of the last interglacial sea-level high stand along the coast of Italy: tectonic implications. Quat. Int. 145-146, 30-54.

Firth, C., Stewart, I., McGuire, W.J., Kershaw, S., Vita-Finzi, C., 1996. Coastal elevation changes in eastern Sicily: implications for volcano instability at Mount Etna. In: McGuire, W.J., Jones, A.P., Neuberg, J. (Eds.), Volcano Instability on the Earth and Other Planets. Geol. Soc. London Spec. Publ., vol. 80. pp. 57-74.

Gente, P., Dyment, J., Maia, M., Goslin, J., 2003. Interaction between the Mid-Atlantic Ridge and the Azores hotspot during the last 85 Myr: emplacement and rifting of the hot spot-derived plateaus. Geochem. Geophys. Geosyst. 4 (10), 8514

Hipólito, A., Madeira, J., Carmo, R., Gaspar, J.L., 2013. Neotectonics of Graciosa Island (Azores): a contribution to seismic hazard assessment of a volcanic area in a complex geodynamic setting. Ann. Geophys. 56 (6), S0677.

Instituto Hidrográfico (Ed.), 2000. Arquipélago dos Açores, 2nd edn. Roteiro da Costa de Portugal Instituto Hidrográfico, Lisboa.
Lourenço, N., Miranda, J.M., Luís, J.F., Ribeiro, A., Victor, L.M., Madeira, J., Needham, H., 1998. Morpho-tectonic analysis of the Azores Volcanic Plateau from a new bathymetric compilation of the area. Mar. Geophys. Res. 20 (3), 141-156.

Lucchi, F., 2009. Late-Quaternary marine terrace deposits as tools for wide-scale correlation of unconformity-bounded units in the volcanic Aeolian archipelago (southern Italy). Sediment. Geol. 216, 158-178.

Lucchi, F., Tranne, C.A., Calanchi, N., Rossi, P.L., 2007. Late Quaternary deformation history of the volcanic edifice of Panarea (Aeolian Arc). Bull. Volcanol. 69, 239-257. Madeira, J., Brum da Silveira, A., Hipólito, A., Carmo, R., 2015. Chapter 3. Active tectonics in the central and eastern Azores islands along the Eurasia-Nubia boundary: a review. Geol. Soc. Lond. Mem. 44 (1), 15-32. https://doi.org/10.1144/M44.3.

Marques, F.O., Catalão, J.C., DeMets, C., Costa, A.C.G., Hildenbrand, A., 2013. GPS and tectonic evidence for a diffuse plate boundary at the Azores Triple Junction. Earth Planet. Sci. Lett. 381, 177-187.

Mauz, B., Vacchi, M., Green, A., Hoffmann, G., Cooper, A., 2015. Beachrock: a tool for reconstructing relative sea level in the far-field. Mar. Geol. 362, 1-16. https://doi. org/10.1016/j.margeo.2015.01.009.

Meireles, R.P., Quartau, R., Ramalho, R.S., Rebelo, A.C., Madeira, J., Zanon, V., Ávila, S.P., 2013. Depositional processes on oceanic island shelves-evidence from stormgenerated Neogene deposits from the mid-North Atlantic. Sedimentology 60 (7), 1769-1785. https://doi.org/10.1111/sed.12055.

Miller, K., Kominz, M., Browning, J., Wright, J., Mountain, G., Katz, M., Sugarman, P., Cramer, B., Christie-Blick, N., Pekar, S., 2005. The Phanerozoic record of global sealevel change. Science 310 (5752), 1293-1298. https://doi.org/10.1126/science. 1116412.

Miranda, J.M., Luís, J.F., Lourenço, N., 2018. The geophysical architecture of the Azores from magnetic data. In: Küppers, U., Beier, C. (Eds.), Volcanoes of the Azores. Active Volcanoes of the World Springer Verlag, Berlin, pp. 89-100.

Passaro, S., Ferranti, L., de Alteriis, G., 2011. The use of high-resolution elevation histograms for mapping submerged terraces: tests from the Eastern Tyrrhenian Sea and the Eastern Atlantic Ocean. Quat. Int. 232 (1-2), 238-249.

Pedoja, K., Husson, L., Johnson, M.E., Melnick, D., Witt, C., Pochat, S., Nexer, M., Delcaillau, B., Pinegina, T., Poprawski, Y., Authemayou, C., Elliot, M., Regard, V., Garestier, F., 2014. Coastal staircase sequences reflecting sea-level oscillations and tectonic uplift during the Quaternary and Neogene. Earth-Sci. Rev. 132, 13-38.

Pirazzoli, P.A., Radtke, U., Hantoro, W.S., Jouannic, C., Hoang, C.T., Causse, C., et al., 1993. A one million-year-long sequence of marine terraces on Sumba Island, Indonesia. Mar. Geol. 109 (3), 221-236.

Porębski, S., Gradziński, R., 1990. Lava-fed Gilbert type delta in the Polonez Cove Formation (Lower Oligocene), King George Island, West Antarctica. In: Colella, A., Prior, D. (Eds.), Coarse Grained Deltas. International Association of Sedimentologists Special Publication 10pp. 333-351. https://doi.org/10.1002/9781444303858.ch19.

Quartau, R., Mitchell, N.C., 2013. Comment on "Reconstructing the architectural evolution of volcanic islands from combined $\mathrm{K} / \mathrm{Ar}$, morphologic, tectonic, and magnetic data: the Faial Island example (Azores)" by Hildenbrand et al. (2012). [J. Volcanol. Geotherm. Res. 241-242 (2012) 39-48]. J. Volcanol. Geotherm. Res. 255, 124-126.

Quartau, R., Tempera, F., Mitchell, N.C., Pinheiro, L.M., Duarte, H., Brito, P.O., Bates, R., Monteiro, J.H., 2012. Morphology of the Faial Island shelf (Azores): the interplay between volcanic, erosional, depositional, tectonic and mass-wasting processes. Geochem. Geophys. Geosyst. 13, Q04012. https://doi.org/10.1029/2011GC003987.

Quartau, R., Hipólito, A., Romagnoli, C., Casalbore, D., Madeira, J., Tempera, F., Roque, C., Chiocci, F.L., 2014. The morphology of insular shelves as a key for understanding the geological evolution of volcanic islands: insights from Terceira Island (Azores). Geochem. Geophys. Geosyst. 15, 1801-1826.

Quartau, R., Hipólito, A., Mitchell, N.C., Gaspar, J.L., Brandão, F., 2015a. Comment on "Construction and destruction of a volcanic island developed inside an oceanic rift: Graciosa Island, Terceira Rift, Azores" by Sibrant et al. (2014) and proposal of a new model for Graciosa geological evolution [J. Volcanol. Geotherm. Res. 284 (2014) 32-45]. J. Volcanol. Geotherm. Res. 303, 146-156.

Quartau, R., Madeira, J., Mitchell, N.C., Tempera, F., Silva, P.F., Brandao, F., 2015b. The insular shelves of the Faial-Pico Ridge (Azores archipelago): a morphological record of its evolution. Geochem. Geophys. Geosyst. 16, 1401-1420.

Ramalho, R.S., 2011. Building the Cape Verde Islands, 1st ed. Springer, Berlin. https:// doi.org/10.1007/978-3-642-19103-9. (207 pp.).

Ramalho, R.S., Helffrich, G., Schmidt, D.N., Vance, D., 2010a. Tracers of uplift and subsidence in the Cape Verde Archipelago. J. Geol. Soc. Lond. 167 (3), 519-538. https://doi.org/10.1144/0016-76492009-056.

Ramalho, R.S., Helffrich, G., Cosca, M., Vance, D., Hoffmann, D., Schmidt, D.N., 2010b. Episodic swell growth inferred from variable uplift of the Cape Verde hotspot islands. Nat. Geosci. 3 (11), 774-777. https://doi.org/10.1038/ngeo982.

Ramalho, R.S., Helffrich, G., Cosca, M., Vance, D., Hoffmann, D., Schmidt, D.N., 2010c. Vertical movements of ocean island volcanoes: insights from a stationary plate environment. Mar. Geol. 275, 84-95. https://doi.org/10.1016/j.margeo.2010.04.009. Ramalho, R.S., Quartau, R., Trenhaile, A.S., Mitchell, N.C., Woodroffe, C.D., Ávila, S.P., 2013. Coastal evolution on volcanic oceanic islands: a complex interplay between volcanism, erosion, sedimentation, sea-level change and biogenic production. Earth Sci. Rev. 127, 140-170.

Ramalho, R.S., Helffrich, G., Madeira, J., Cosca, M., Thomas, C., Quartau, R., Hipólito, A., Rovere, A., Hearty, P., Ávila, S.P., 2017. Emergence and evolution of Santa Maria Island (Azores) - the conundrum of uplifted islands revisited. Geol. Soc. Am. Bull. 129, 2017. https://doi.org/10.1130/B31538.1.

Rusu, L., Guedes Soares, C., 2012. Wave energy assessments in the Azores islands. Renew. Energy 45, 183-196.

Schwartz, D.M., Soule, S.A., Wanless, V.D., Jones, M.R., 2018. Identification of erosional terraces on seamounts: implications for interisland connectivity and subsidence in the Galápagos Archipelago. Front. Earth Sci. 6, 88. https://doi.org/10.3389/feart.2018. 
00088 .

Serralheiro, A., 2003. A geologia da ilha de Santa Maria, Açores. Açoreana 10 (1), 141-192.

Serralheiro, A., Alves, C.A.M., Forjaz, V.H., Rodrigues, B., 1987. Carta Vulcanológica dos Açores. Ilha de Santa Maria na escala 1/15 000 (folhas 1 e 2). Serviço Regional de

Protecção Civil dos Açores, Universidade dos Açores and Centro de Vulcanologia.

Sibrant, A.L.R., Hildenbrand, A., Marques, F.O., Costa, A.C.G., 2015. Volcano-tectonic evolution of the Santa Maria Island (Azores): implications for paleostress evolution at the western Eurasia-Nubia plate boundary. J. Volcanol. Geotherm. Res. 291, 49-62.

Trenhaile, A.S., 2002. Modeling the development of marine terraces on tectonically mobile rock coasts. Mar. Geol. 185, 341-361.

Trenhaile, A.S., 2014. Modelling the effect of Pliocene-Quaternary changes in sea level on stable and tectonically active land masses. Earth Surf. Process. Landf. 39, 1221-1235. https://doi.org/10.1002/esp.3574.

Trenhaile, A.S., 2015. Coastal notches: their morphology, formation, and function. Earth Sci. Rev. 150, 285-304. https://doi.org/10.1016/j.earscirev.2015.08.003.

Zazo, C., Goy, J.L., Hillaire-Marcel, C., Gillot, P.Y., Soler, V., González, J.Á., Ghaleb, B., 2002. Raised marine sequences of Lanzarote and Fuerteventura revisited - a reappraisal of relative sea-level changes and vertical movements in the eastern Canary Islands during the Quaternary. Quat. Sci. Rev. 21 (18-19), 2019-2046. https://doi. org/10.1016/S0277-3791(02)00009-4.

Zazo, C., Goy, J.L., Dabrio, C.J., Soler, V., Hillaire-Marcel, C., Ghaleb, B., et al., 2007. Quaternary marine terraces on Sal Island (Cape Verde archipelago). Quat. Sci. Rev. 26 (7-8), 876-893.

Zbyszewski, G., Ferreira, O.V., 1960. Carta geológica de Portugal, Ilha de Santa Maria (Açores), scale 1:50 000. Serviços Geológicos de Portugal. 